The reaction of asset markets to Swiss National Bank communication

Angelo Ranaldo and Enzo Rossi

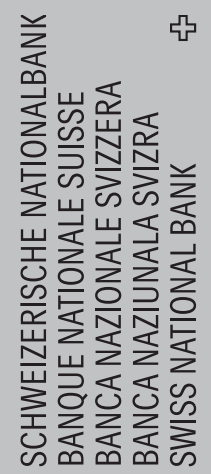

隹

(4)

0

ro

(

$\frac{07}{\frac{1}{2}}$

שי

U

$\frac{n}{3}$ 
The views expressed in this paper are those of the author(s) and do not necessarily represent those of the Swiss National Bank. Working Papers describe research in progress. Their aim is to elicit comments and to further debate.

ISSN $1660-7716$

๑ 2007 by Swiss National Bank, Börsenstrasse 15, P.0. Box, CH-8022 Zurich 


\title{
The reaction of asset markets to Swiss National Bank communication
}

Angelo Ranaldo and Enzo Rossi ${ }^{\#}$

October 2007

\begin{abstract}
In this paper we analyze high-frequency movements in Swiss financial markets in reaction to real-time communication by the Swiss National Bank. Our analysis of central bank communication encompasses official speeches and interviews, not only monetary policy announcements. We examine the reactions of the currency market, the bond market and the stock exchange. The evidence suggests that speeches and interviews, along with monetary policy announcements, engender a significant price reaction. This paper sheds light on the relevance of communications other than monetary policy announcements.
\end{abstract}

\footnotetext{
\# Angelo Ranaldo and Enzo Rossi are at the Swiss National Bank. We thank Werner Abegg, Petra GerlachKristen, Marcel R. Savioz and an anonymous referee for their valuable comments. The views expressed herein are those of the authors and not necessarily those of the Swiss National Bank, which does not accept any responsibility for the contents and opinions expressed in this paper. Contact information: Swiss National Bank, Research Department, Börsenstrasse 15, P.0. Box 2800, Zurich, Switzerland. e-mail: angelo.ranaldo@snb.ch, enzo.rossi@snb.ch, Phone: ++41.44.6313826, Fax: ++41.44.6313901.
} 


\section{Introduction}

Communication by central banks has attracted considerable attention in the last few years. It is seen as instrumental in achieving transparency and a high degree of accountability. Moreover, by communicating their intentions, central banks affect the expectations of financial market participants and financial assets and thus increase the effectiveness of monetary policy (Blinder, 1998; Woodford, 2003; Bernanke, 2004). Ideally, monetary policy is able to respond less aggressively than would otherwise have been necessary.

Despite its relevance, relatively little research has been done into the effects of central bank communication. This paper contributes to this literature by analyzing whether communication by Swiss National Bank (SNB) management affects Swiss asset markets using high-frequency data. The paper goes beyond previous studies in three important respects. First, it not only investigates the reactions of asset markets to official policy announcements but also to speeches and interviews. Second, it analyzes the reaction of three financial assets: currency rates, stocks and bonds. Third, it provides a new database derived from internal SNB information and external newswire reports.

The paper's findings are that SNB communication does indeed affect asset markets. They react not only to official policy statements but also to speeches and interviews. Market participants actively monitor and promptly respond to central bank communication. While official policy announcements cannot be used in a discretionary way, speeches and interviews allow the monetary authorities to flexibly inform market participants about past and ongoing economic activity as well as about impending policy. The policy conclusions of this paper are that communication tools may be seen as additional policy instruments which, however, have to be handled with circumspection.

This paper's conclusion is partially at odds with Reeves and Sawicki (2005) who found that in the UK, speeches and testimony to parliamentary committees are less informative than the Bank of England's Minutes and Inflation Report. The Swiss case also contrasts with Kohn and Sack (2004) who found a significant response in interest rate expectations to the Federal Open Market Committee and to Chairman Greenspan's testimony to Congress, but no reaction to ordinary speeches - the most comparable form of communication across countries.

After reviewing the existing literature and related research, this paper describes the SNB's monetary policy concept and its communication instruments. Next, it presents the empirical framework used to estimate the short-term effects of communication on selected Swiss asset 
prices, followed by a description of the data. Then, the results are shown. The final section presents conclusions.

\section{Literature survey}

The burgeoning body of literature on central bank communication and transparency can be parsed into different categories. On the one hand there is a good deal of theoretical work covering the welfare implications associated with central bank transparency. No consensus on whether higher central bank transparency is generally beneficial has emerged (yet). ${ }^{1} 0 \mathrm{n}$ the other, a fast expanding empirical literature hints at overall positive effects of transparency. The empirical research has tackled the issue from different angles.

One broad research area emphasizes the macroeconomic implications of varying degrees of central bank transparency and communication. For instance, Chortareas et al. (2002) document a decrease in inflation following increased central bank transparency in a large country-sample. Van der Cruijsen and Demertzis (2005) found that the sensitivity of private sector inflation expectations to past inflation has diminished against the backdrop of greater transparency. Geraats et al. (2006) report an increase in policy flexibility and a decrease in inflation expectations. A related group of empirical contributions encompasses studies focusing on communication strategies (Blinder et al., 2001; Ehrmann and Fratzscher, 2005a; Blinder, 2006a).

Another investigative approach concentrates on the effects of macroeconomic news releases or, more specifically, of central bank communication on financial markets. One research issue is whether there is a link between transparency and monetary policy predictability. The evidence for transparency increasing monetary policy predictability seems compelling. See, among others, Gerlach-Kristen (2004), Kohn and Sack (2004), Ehrmann and Fratzscher (2004; 2005b, 2005c), Wilhelmsen and Zaghini (2005), and Swanson (2006).

A further line of research, and the one adopted in this paper, focuses on the role of macroeconomic and public news announcements as a source of financial market reactions. The vast literature on macro announcements offers ample evidence that macroeconomic news affect asset prices. The contributions can be broadly categorized according to the market researched. One focal point of literature linking macroeconomic news and the variation of securities prices is the foreign exchange market. A selection of papers includes Andersen et al. (2003), Fratzscher (2004), and Jansen and de Haan (2005). Another focus of research is bond market reactions, researched, for instance, by Cook and Hahn (1989),

\footnotetext{
${ }^{1}$ See, for instance, Geraats (2002), Woodford (2005), and Jordan and Rossi (2006) for recent overviews.
} 
Balduzzi et al. (2001), Gürkaynak, Sack and Swanson (2005a) and Gürkaynak et al. (2005). The third focal point has been the stock market, whose reactions have been scrutinized by, among others, Bomfim (2003), Poitras (2004), and Zebedee et al. (2005). Some studies examine announcement effects on more than one financial market, as, for instance, Ederington and Lee (1993, 1995), Clare and Courtenay (2000, 2001), Fair (2003), Faust et al. (2003) and Rigobon and Sack (2006). ${ }^{2}$

A particular line of research on macroeconomic news and financial assets, to which our paper contributes, focuses on information emanating from central banks. For instance, Bell and Windle (2005) and Reeves and Sawicki (2005) looked into the reaction of sterling interest rates to Bank of England communication. Jansen and De Haan (2005) studied the reaction of euro-dollar exchange rates to statements by the European Central Bank and national central bank officials. Kohn and Sack (2004) investigated the response of various U.S. financial variables to FOMC statements accompanying interest rate decisions and to former chairman Greenspan's testimony to Congress. Bomfim (2003) studied the influence of FED announcements on the U.S. stock market.

\section{SNB's monetary policy concept and communication tools}

The SNB's monetary policy concept, which grew out of 25 years of monetary targeting, consists of three elements. The first element is a definition of what the SNB considers compatible with price stability - a rise in the CPI of less than $2 \%$ per annum that acts as a nominal anchor. The second element is an inflation forecast issued quarterly following a monetary policy assessment. ${ }^{3}$ Monetary policy assessments are held in mid-March, mid-June, mid-September and mid-December ("scheduled decisions"). However, until the end of 2002 the inflation forecasts, although computed quarterly, were made public only semi-annually. The third element is a published operational target range for the three-month Libor as a reference interest rate. Normally, this range has a width of 100 basis points. Additionally, the SNB announces where in this band it wishes the Libor to remain. ${ }^{4}$ Typically, this reflects the midpoint of the announced target range. As a rule, the target range is reviewed by the

\footnotetext{
${ }^{2}$ Most studies linking announcement effects and asset prices focus on the relationship between domestic news and domestic asset prices. The implications for domestic asset prices of foreign news have been explored less. Noticeable exceptions are, for instance, Faust et al. (2003), Goldberg and Leonard (2003), Gürkaynak et al. (2005), Andersen et al. (2005) and Loderer and Mittermayer (2006).

${ }^{3}$ The forecast is generated under the assumption that the current reference interest rate remains unchanged during the forecasting horizon.

${ }^{4}$ Although the SNB does not have direct control over the three-month Libor, it controls it indirectly through its daily Repo transactions with banks, which allow a rather close control of the very short-maturity rates, especially the overnight and the one-week rate. Through arbitrage and expectations the three-month Libor is quite closely linked to very short-term rates.
} 
Governing Board at the quarterly monetary policy assessment. If necessary, the Board may change the target range at short notice between regular meetings, giving rise to what we term "unscheduled decisions".

Although the SNB has a decades-long history of regular explanation of its monetary policy decisions to market participants and the public, it has steadily refined its communication policies and substantially increased its transparency. ${ }^{5}$ In order to communicate its current assessment of economic developments and its thinking about future policy decisions, today's SNB resorts to a broad set of communication tools. First and foremost, a detailed press release - comprising i) assumptions for the global economy, ii) a comprehensive appraisal of domestic economic activity and its outlook, iii) an evaluation of monetary developments, iv) inflation perspectives based on ii) and iii) and the explanation of the monetary policy decision, $v$ ) the target range for the Libor and the envisaged interest rate within this band and vi) an inflation forecast based on the assumption that the new decided Libor will remain constant over the forecasting period of three years - is made available immediately after the quarterly monetary policy assessment. Great emphasis is laid upon the reasoning behind each decision, which is explained irrespective of whether policy settings have been changed or not. In the June and December assessments this information is delivered at a press conference.

A few weeks later, the SNB publishes a Monetary Policy Report. In it, the SNB issues statements on the development of the principal indicators that were taken into account, describes the latest monetary and economic developments, conveys its views on the economic situation and explains the inflation forecast more thoroughly. Moreover, the SNB submits an annual accountability report to the Federal Assembly in which it explains in detail how it has fulfilled its statutory mandate, in particular the conduct of monetary policy, and also describes the economic and monetary developments in the year under review. In addition, the Chairman of the Governing Board testifies before parliamentary commissions. Further means of communication include speeches and interviews delivered by the Governing Board and other senior officials in which supplementary information on Swiss monetary policy is offered. In this paper we will analyze the market impact of monetary policy decisions, speeches and interviews.

\footnotetext{
${ }^{5}$ See Jordan and Rossi (2007). The importance attributed to transparency for conducting monetary policy at the SNB has been stressed by Chairman Roth on several occasions. See, e.g., Roth $(2002,2006)$.
} 


\section{Estimation procedure}

\subsection{Non-parametric event study}

Event studies can in principle be carried out by means of parametric or non-parametric methods. Parametric event studies make specific assumptions regarding market models and distribution of excess returns. Ever since Cook and Hahn's early (1989) paper assessing markets' reaction to monetary policy actions embedded in a parametric event study, numerous researchers have adopted and refined this approach. Critical in these studies is the correct measurement of policy surprises. A variety of different techniques and financial instruments have been employed to model the surprise component of an announcement. ${ }^{6}$

We have opted for a non-parametric analysis, which has several advantages. By choosing a non-parametric procedure, we can overcome the difficulties of replicating the surprise of monetary policy communication. Second, non-parametric event study approaches are free of specific assumptions regarding return distribution and price formation behaviour in the market in question. Third, a key advantage of our event study approach is that it avoids having to classify communication. Unlike much of the literature, we can thus circumvent the danger of misclassifying statements and their intended content. Fourth, this approach allows us to analyze communication impacts event by event. We estimate the statistical significance of price impacts surrounding communication events by means of $t$-statistics. We refer to two-tail statistics for the inequality between the price changes related to a specific event and the mean overall returns (inequality hypothesis). Note that we perform the two-sample equal variance (homoscedastic) test. This represents a more stringent test than the heteroscedastic hypothesis. Also, we calculate the mean overall return of the statistical population rather than the return during non-communication periods only. Both aspects give the probability associated with a Student's $t$-test for equality in means an upward bias and lead to a more likely rejection of the inequality hypothesis. The standard errors for the $t$-test are based on the population's standard deviation. We also considered a more contingent and time-variable definition of standard deviation. For instance, we have considered the return standard deviation at the same time of day as each specific event occurred. This allows us to take into account some effects due to intraday seasonalities. We have also conditioned return variability on the recent past by considering the last 8,26 or 52 weeks. Our findings remain essentially unchanged.

\footnotetext{
${ }^{6}$ Rigobon and Sack (2006) argue that the event study estimates suffer from a significant shortcoming due to mismeasurement of the macroeconomic news so that the measured data surprises explain only a small portion of the variation in asset prices and monetary policy expectations. They propose two new approaches to better account for the noise in measured data surprises. Using these estimators they find that incoming news generally has a much bigger impact on asset prices than captured by the event study approach.
} 
We also attempt to analyze the statistical impact related to a specific communication tool. To this end, we employ non-parametric measures comparing the price impacts related to a given communication instrument and the overall price changes. Specifically, we examine whether the mean, median and variance of intraday returns clustered around communication events are likely to be equal to those of the population. The non-parametric tests shown in the tables are the Anova F-test, the Median Chi-square test and the Variance F-test. Other methodologies for the mean, median and variance test have been considered. ${ }^{7}$ These additional measures - not reported in the paper - are supportive of its results.

To ease the reading of our results, we organised the tables as follows. First, we present the reaction asset by asset, starting with the forex, followed by equities and finally bonds. Second, each table exhibits significant event-specific and communication-specific results. Accordingly, we report intraday price impacts on an event-by-event basis (size of price impact and related $t$-test), followed by the overall impact of each communication tool measured by the Anova F-test, the Median Chi-square and the Variance F-test. Third, for each market we looked at the three communication events in the following order: monetary policy announcements, official speeches, and interviews. We began by investigating scheduled and unscheduled policy announcements separately. In so doing, we calculated statistical tests comprising all monetary policy announcements, a subsample including only the scheduled events, i.e. scheduled monetary policy announcements and Ordinary General Meetings of Shareholders and bank authorities, and finally scheduled monetary policy assessments only. This allowed us to infer whether the market reacted to both scheduled and unscheduled monetary policy announcements. Finally, we considered interviews and speeches reported either during working hours or out of business hours or for which it was not possible to establish the exact intraday time. To opportunely report these information releases, we organized the tables on speeches and interviews into two panels. As explained below in more detail, the upper panel shows the intraday effect within trading hours. The lower panel illustrates the daily effect of off-market news.

Although knowledge of whether the market response corresponded with policymakers' intentions would constitute an (additional) important insight from a policymaking point of view, our analysis is limited to the description of the market reactions. We refrained from any normative interpretation of the results.

\footnotetext{
${ }^{7}$ For the median tests, we also estimated the Wilcoxon signed test and the Mann-Whitney test. We also considered additional variance tests such as Singel-Tukey, Barlett and Levene methods.
} 


\subsection{Sampling interval}

While earlier papers on asset price movements used monthly or even quarterly data, event study literature employs daily data. However, even this seems insufficient. First, earlier work has shown that the average effect of announcements is felt very quickly. ${ }^{8}$ The use of daily data, including the effect of announcements and all other information impacting the market that day, leads to very imprecise estimates of the announcements' effects, especially on highly variable asset prices, such as foreign exchange. For instance, attempts to identify systematic relationships between the surprise component of macroeconomic data releases and one-day exchange rate changes have not been successful, as shown by Hardouvelis (1988) and Edison (1997).

To mitigate these problems, higher-frequency data which shrinks the time period around the policy decisions has been used in more recent work. High-frequency, intraday data exhibits two appealing characteristics: First, by narrowing time windows around a specific event, it becomes much less likely that any other cause can mistakenly be identified as having determined market reactions. Second, estimations are more efficient in terms of identification and evaluation of single outliers.

Thanks to data availability, the more recent contributions to the literature make use of intradaily data. ${ }^{9}$ Thus, in order to characterise the response of asset markets more accurately, we also use intraday data coupled with the exact time of an SNB announcement. While most of the previous literature on intraday event study confines the analysis to a short period of time, we also compare the reaction of financial markets over different event windows varying according to the form of communication. The shortest time window we allow for is 5 minutes, the longest includes a 24-hour window following the arrival of information from monetary policymakers, excluding overnight movements.

\subsection{Sample period}

Another feature of previous research into asset price movements over short windows of time around announcements is its customary restriction to a short sample period for lack of intradaily data over long spans. ${ }^{10}$ We agree with Faust et al. (2003) that using a long time

\footnotetext{
${ }^{8}$ Balduzzi et al. (2001) describe this phenomenon for the bond markets and Andersen et al. (2003) for the forex markets.

${ }^{9}$ Moving from daily to intradaily frequency may affect the outcomes significantly. For instance, Gürkaynak, Sack and Swanson (2005b) obtain a tripling of $R^{2}$ in a regression of US equity prices on the surprise component of the change in the federal funds rate target by switching from a daily to intradaily windows.

${ }^{10}$ Exceptions are Fair (2003), Faust et al. (2003) and Gürkaynak, Sack and Swanson (2005b).
} 
span is appealing, and stress the benefits of high-frequency data. A longer series of high frequency data contributes to the precision of estimates and allows for the exploration of the possibility that the effects of announcements on asset prices may vary over time. We focus our attention on the period beginning with the implementation of the SNB's new monetary policy framework, thus including information from January 2000 to December 2005. While the market impact of communication under two different monetary policy regimes would constitute an interesting line of research, lack of sufficient observations during the monetary targeting time frame creates an insurmountable barrier to empirical examination. Hence, given that monetary policy decisions are taken quarterly, our sample of policy announcements is relatively short. It does nonetheless incorporate a period featuring interest rate increases, a period with historically low interest rates, a bull and bear equity market and a series of significant shocks to the economy, including the impact of $9 / 11$ and a sharp rise in oil prices.

\subsection{Methodological limits}

There are at least four methodological limits to point out. First, the accuracy of the results depends significantly on the extent of broadcasting systems information taken into account and the precision with which their reports are captured. Given that it is impossible to track all broadcasting systems, one methodological limit to our analysis is that it is restricted to three leading newswire companies: Dow Jones Newswires, Reuters and Bloomberg. However, there are many others which may report on communication events by the SNB, such as AWP (AG für Wirtschafts-Publikationen), SDA (Schweizerische Depeschenagentur AG), etc.

A second limit refers to the precision with which the event time can be time-stamped. Several issues come into play here. While the actual time of a monetary policy announcement can be precisely identified, there may be a mismatch between a speech or interview and the time of a related news release. On the one hand, a speech may be given ahead of the official time, followed by a waiting period (also called "embargo"). Thus, information may become publicly available before the official embargo elapses. As a result of these methodological constraints we may find market movements ahead of the reporting time of news broadcasts tracked in this study. When it comes to interviews, it is possible that SNB-related information circulates among market participants prior to newswire reporting. The reason is that unlike speeches, the dates of interviews are not always publicly available in advance. Occasionally, broadcasting companies call up the SNB's press office to check the content of an interview before reporting on it. Information may therefore already be in circulation when the first newswire appears. Early market 
fluctuations (prior to the first newswire release) are thus possible. A related limit is linked to the intraday time windows, set to 5 minutes. This 5 minute rule means that all events must be rounded up or down to the nearest 5-minute time interval, even if an event was reported in between. ${ }^{11}$

Third, even if we observe significant price movements surrounding SNB communications, we cannot exclude that these are due to other causes. We distinguish two possible biases. First, although the intraday analysis enhances the measurement precision of the event impact, many other occurrences that we did not control for can significantly affect asset prices. For example, it is difficult to infer whether speeches and interviews reported in the wake of 9/11 had a genuine market impact. To account for this possible bias, we also report price movements the day before and after the SNB communication event. Second, there may be overlapping SNB communication events that have to be taken into account. If overlapping communication events occurred, we reported them in footnotes to each table. Some of them explain apparent early price movements.

Fourth, by using high-frequency data we attempted to nail down the effects of SNB communication on financial markets distinct from other news. We grouped the intraday data within successive time windows, thus extending the observation period. Given that we did not focus exclusively on market behaviour narrowly confined around communication events, we cannot exclude that the genuine market reaction to SNB communication is being offset by other news, producing a price reversal. Therefore, we cannot rule out that other incoming news may make a significant communication event ineffective over a longer timeframe.

\section{Data and summary statistics}

This section describes the data used in the empirical analysis. We study the impact of SNB communication using high-frequency intraday data on the CHF/USD, the Swiss Bond Index (SBI) and, as the measure of the stock exchange, the Swiss Performance Index (SPI). Observations run from January 2000 to December 2005. As pointed out above, the beginning of the sample is dictated by the onset of the new monetary policy concept adopted by the SNB. Data on the CHF/USD rate was kindly provided to us by the SwissSystematic Asset Management SA, Zurich. The data on both the SBI and SPI were placed at our disposal by the SWX Swiss Exchange. ${ }^{12}$ Furthermore, we use daily data, obtained from

\footnotetext{
${ }^{11}$ For instance, if a newswire report occurs at $1.58 \mathrm{pm}$ it is rounded up to $2 \mathrm{o}^{\prime}$ clock. If, however, a report is clocked up at 1.57 p.m. it is rounded down to 1.55 .

${ }^{12}$ We thank Richard Meier and Marc Berthoud (both at SWX) for their collaboration and assistance.
} 
Datastream, measured at one p.m. GMT time. In order to capture the surprise elements of communication we relied on the movements of the Futures written on the three-month Libor in a 20-minute window following an SNB announcement. These data are from the SNB. ${ }^{13}$

The data contain information on transaction prices and the related time stamp to the nearest second of all index changes or representative forex quotes that occurred in our sample period. The data set has been organised into 5-minute time intervals. If no trades occurred in a given 5-minute interval, we copied down the price from the previous time interval. We carefully checked the presence of outliers and all other data properties. Indeed, we encountered irregular records for the SBI from $28 / 11 / 2002$ to $7 / 11 / 2003$. The SWX confirmed that this was due to a calculation problem in bond coupon values. For that reason, we excluded this period from the bond analysis. ${ }^{14}$

As described in Section 2, the SNB engages in intensive communication activities. We focus on three forms: speeches as well as interviews (both by members of the Enlarged Governing Board) and monetary policy announcements by the Governing Board, both scheduled and unscheduled. Incidentally, these communication forms exhibit a methodological advantage as their dates are - apart from the few unscheduled assessments - published well in advance, so that no endogeneity problem found in the literature on central bank communication blurs our results. ${ }^{15}$

For the sake of completeness and extension of observations in the sample we added the remarks of the Chairman of the Board made during the Ordinary General Meeting. The General Meeting is held once a year, as a rule in April. ${ }^{16}$ The communication sample had to be constructed from scratch. To this end, we first fell back on an unpublished daily report drawn up by the SNB's press office that provides coverage of highlights reported by the media. From these publications we selected all articles referring to SNB speeches, interviews and monetary policy decisions. Once our sample of speeches was constructed, we compared it with the SNB's in-house statistics. By contrast, our sample of interviews contains only those covered by the media. Speeches and interviews were included irrespective of their content. If we simultaneously came across newswire reports alluding to SNB spokesmen

\footnotetext{
${ }^{13}$ We are grateful to Marcel Zimmermann (SNB).

${ }^{14}$ Unfortunately, all other relevant indices on Swiss bonds provided by the SWX are also affected by this problem. Moreover, SWX does not plan to recalculate these intraday data. Therefore, it is impossible to find a better alternative to the total bond index.

${ }^{15}$ Our database also contains communications by SNB spokesmen in which an endogeneity problem may arise, as spokesmen interventions may occur in reaction to particular market conditions. However, spokesmen communication represents only $16 \%$ of interviews - too few to affect the results significantly.

${ }^{16}$ Owing to the SNB's public mandate, the powers of the Shareholders' Meeting are limited compared with joint-stock companies under private law.
} 
comments, we added them to our database. The collected information was then used to do a search of pertinent references in Bloomberg, Dow Jones and Reuters. For the information provided by Dow Jones and Reuters we recurred to Factiva ${ }^{\circledR}$, from Dow Jones, entering several keywords, such as "Swiss National Bank", "SNB", "Monetary policy", the name of speaker or interviewee and others. Newswire services' information is particularly useful since they provide a time stamp of the news release to the nearest minute, enabling us to arrange precise intraday time windows around the earliest newswire report. The issuance time of the monetary policy announcements was provided by the SNB's press office. ${ }^{17}$ Eventually, we complemented our data set with reports on the traditional year-end meetings of the Chairman of the Board with the cabinet and with information relating to elections and resignations of the Enlarged Governing Board members. Although it comprises a good deal of information, we did not consider the quarterly Monetary Policy Report for it is not available until nearly four weeks (internet) and five weeks (hardcopy) after the latest monetary policy assessment. ${ }^{18}$ Nor is there any accompanying press conference on its publication day. ${ }^{19}$ Neither did we take into account the testimonies to the parliamentary commissions delivered by the Chairman of the Governing Board. Though an important part of the SNB's accountability, they received no particular media attention. ${ }^{20}$ Note also that no Minutes of the monetary policy meetings are made publicly available. ${ }^{21}$

Table 1 offers an overview of the three communication forms at issue in this study, distinguished by the time of news arrival (Panel A) and by year (Panel B). From the first row we can infer that there were 36 monetary policy announcements (i.e. official joint communication by the Governing Board), 146 official speeches and 177 interviews. The other three rows in Panel A display the three communication forms according to three time frames of newswire reporting. The first time frame comprises communication reported on during trading hours. The second frame includes reports issued after market closure, i.e. five o'clock p.m. The third frame catalogs weekend communication.

Panel B denotes the time pattern of interviews and speeches. While the number of speeches has clearly increased, beginning with 14 in 2000 and reaching a maximum of 36 in 2005,

\footnotetext{
${ }^{17}$ We are deeply indebted to Roland Baumann.

${ }^{18}$ The time lag is largely attributable to the long translation process required for the simultaneous release in German, French and English.

${ }^{19}$ In terms of importance the SNB's Monetary Policy Report is not comparable with, e.g., the Inflation Report by the Bank of England's MPC whose publication is accompanied by an hour-long press conference with three senior bank officials.

${ }^{20}$ In any case, only a few data points would be available, for the Chairman of the Governing Board has only been required to testify before the parliamentary commission since the enactment of the new National Bank Act in May 2004.

${ }^{21}$ Normally, the SNB opens its internal records only after 30 years (Rich, 2003, fn. 6). The rationale for abstaining from publishing the Minutes is discussed, e.g., in Jordan and Rossi (2007).
} 
the number of interviews per year has, by contrast, diminished of late. It was amplified in the first half of the sample, reaching 38 in 2002 and 2003, before dropping to around 20 in 2004 and 2005.

TABLE 1 ABOUT HERE

Table 2 provides a detailed summary of monetary policy announcements which are parsed into scheduled (S) and unscheduled $(U)$ monetary policy decisions on the one hand and General Meetings of the SNB's stockholders and bank authorities (G) on the other. Accordingly, six Stockholders' General Meetings were held while 30 monetary policy decisions were announced. Twenty-three resulted from a scheduled meeting while seven were made between scheduled meetings. Three distinct policy phases can be distinguished. The first phase covers the period from 20 January 2000 to 8 December 2000 and is characterised by rising interest rates. The second phase, from 22 March 2001 to 18 March 2004, is marked by falling and a long period of exceptionally low short-term interest rates. The third phase begins in June 2004 and marks the gradual return to a level of short-term interest rates commensurate with the historical average.

Overall, the target range for the three-month Libor or its level was changed fourteen times. Half of the interest rate moves were decided on at regularly scheduled policy meetings. The size of interest rate steps announced at regular meetings varies from $25 \mathrm{bp}$ to $75 \mathrm{bp}$. Since 2004 rate changes have been confined to $25 \mathrm{bp}$. All rate changes taken at unscheduled meetings occurred during the first half of the sample period. Specifically, in the first three years following the introduction of the inflation-based monetary policy concept, two unscheduled decisions occurred per year, i.e. on 20 January and 3 February 2000, on 17 and 24 September 2001 and on 2 May and 26 July 2002. The last unscheduled event took place on 6 March 2003, dominated by an appreciation of the Swiss franc probably ensuing from pervasive fears of deflation and the franc's role as a safe-haven. Unscheduled decisions have one common denominator in that the size of target adaptations amounted to $50 \mathrm{bp}$. While interest rates were increased in the first two unscheduled meetings, they were cut in all other instances. More accurately, while the target range was kept unchanged at the first decision announced outside the regular calendar, the target for the 3-month Libor was 
moved from the middle to the upper part of the range. At the second unscheduled decision the target range was raised by $50 \mathrm{bp}$ while the target for the Libor was kept unchanged in the middle section of the range. The two rate cuts decided at inter-meeting dates in September 2001 were called for in the aftermath of $9 / 11 .^{22}$

From the table we can infer very few policy reversals. Using Blinder's (2006b) definition that a policy reversal is a change in direction within three months, we count only one policy reversal. Widening the window to four months adds one more reversal. Not only this apparent aversion to policy reversals is in line with other central banks but also the preference for gradualism. According to Blinder (2006b, p. 32), the share of rate changes of 25 bp or less was $79 \%$ for the Fed, $88 \%$ for the BoE, and $89 \%$ for the Riksbank. At the SNB, since inception of the new monetary policy concept the share of rate changes of $25 \mathrm{bp}$ or less was $73 \%$ while the share of rate changes of $50 \mathrm{bp}$ amounted to $23 \%{ }^{23}$

Table 2 also includes the official time of SNB news releases. From it we can take that decisions linked to scheduled monetary policy assessments were made public around 9:30 a.m. (June and December) or around 2 p.m. (March and September). General Meetings always started at 10 a.m. Unscheduled decisions were communicated at varying times and, with the exception of 17 September 2001, during working hours. The last two columns of this table show the extent to which market participants were surprised by the Board's joint communication and the corresponding $t$-statistics. A positive value of surprise hints at an unexpectedly high interest rate decision whereas a negative surprise value represents an unexpectedly low interest rate outcome. Overall, positive and negative surprises were more or less equal. To measure the market surprises we recurred to the three-month Futures rates quoted in the first 20 minutes after the first newswire report. ${ }^{24}$

TABLE 2 ABOUT HERE

\section{Market reaction to SNB communication}

Although the event study literature has provided a number of insights about the effects of macroeconomic data releases on monetary policy expectations and asset prices, the

\footnotetext{
${ }^{22}$ The first of the two rate cuts was announced three days ahead of the regular assessment in a coordinated effort with the FED and the ECB to dampen market uncertainty.

${ }^{23}$ If we consider only the decisions that implied a change in the mid-point target interest rate, then $50 \%$ of policy moves involved a step of $50 \mathrm{bp}$; the share of policy moves of $25 \mathrm{bp}$ reduces to $43 \%$.

${ }^{24}$ For lack of data, the surprise component of the first two communications contained in Table 1 was captured by the changing of the three-month Libor with respect to the previous day.
} 
estimated effects have in general been found to be relatively small. This has been demonstrated even for those assets that are reckoned to be very sensitive to near term monetary policy expectations. Independent of reaction size, the qualitative findings are revealing. One result obtained from high-frequency data is that price adjustments to announcements generally occur within one to twenty minutes after the event.

In this section we examine the impact of different communication tools employed by the SNB on three distinct financial markets. In subsection 1 we analyze the response of the CHF/USD exchange rate. Subsection 2 looks into the stock exchange and subsection 3 deals with the bond market.

The SNB has long been concerned that it be understood by market participants and the public. Clear and honest communication is a prerequisite for transparency. A transparent information framework may be achieved by timely and thorough communication and explanation of the policy decisions which, as a rule, are taken on a quarterly basis at the monetary policy assessments. As follows from Table 1, the SNB has also made extensive use of speeches and interviews to promulgate its views between official policy decision meetings. Additional tools of communication may improve the regularity and frequency of information flow and thus enhance central bank transparency. Based on this reasoning, we first investigated whether monetary policy decisions affected financial markets. We then analyzed whether financial markets reacted to interviews and speeches. If so, they can be seen as conveying additional information to market participants. Used effectively, they can, among other things, improve the SNB's transparency, allowing financial markets to better anticipate the monetary policy decisions well in advance of the scheduled day. As a corollary, the effect on asset yields may be visible ahead of a monetary policy announcement, leaving the markets less affected on the day of a scheduled decision. ${ }^{25}$ If, conversely, significant reactions occur only at the time of regular and pre-announced monetary policy assessments, interviews and speeches would not appear to convey significant information regarding monetary policy.

\subsection{Effect on exchange rates}

Table 3.1 summarizes the impact of monetary policy decisions (scheduled S or unscheduled $\mathrm{U})$ and statements made at the General Meeting of the Stockholders and bank authorities

\footnotetext{
${ }^{25}$ In a similar vein, Haldane and Read (2000) show that a reduction in the markets' uncertainty about the central bank's reaction function implies that market prices will react less to monetary policy changes since market participants are better able to anticipate them, and more fully to news about the state of the economy, in particular macroeconomic data releases on which the reaction function is conditioned.
} 
(G) on the CHF/USD rate. ${ }^{26}$ We constructed six time windows. The first time window captures exchange rate movements 15 minutes ahead of an announcement while the second window covers the reaction in the 5 minutes immediately following an announcement. The third window covers the market's behaviour from 5 to 15 minutes after a communication event. In the remaining three time windows the interval is widened to 15 minutes, i.e. from 15 to 30 minutes, from 30 to 45 minutes and from 45 to 60 minutes after an announcement. Note that in the analysis we can only cover six (of the seven) unscheduled monetary policy announcements, because the $50 \mathrm{bp}$ drop in the interest rate target decided on 17 September 2001 was made public outside of business hours.

At least four relevant observations emerge from Table 3.1. First, SNB policy rate decisions affected the CHF/USD rate on 10 occasions out of 29 (34\%); 6 coincided with scheduled meetings and 4 with unscheduled meetings. The bulk occurred in the first part of the sample period, with the last significant effect dating back to 17 June 2004, when the target band was raised after five quarters of historically low interest rates. Second, remarks during the General Meeting never moved the exchange rate significantly. Third, the significance of the impact occasionally changed between time windows. For instance, on 3 February 2000, the Swiss franc depreciated significantly five minutes after policy communication. In the subsequent time window, however, the currency appreciated. ${ }^{27}$ In most cases the effect was unambiguous. The Swiss franc depreciated six times, and appreciated four times. Fourth, the most significant effects were recorded in the first 10 minutes after a policy announcement. Hence, exchange rates appear to adjust quickly to news.

At the bottom of Table 3.1 we present three tests covering the mean, the median and the variance of market reactions. They indicate whether an official interest rate announcement per se had a significant impact on the forex market. The tests show that monetary policy announcements had a strong effect in terms of mean, median and variance of asset prices. The results suggest that monetary policy decisions affected the CHF/USD within 15 minutes of an announcement, although some effect is still observable after 15 to 30 minutes. As shown in the last three rows of Table 3.1, these effects remain strong even after considering scheduled announcements only.

\section{TABLE 3.1 ABOUT HERE}

\footnotetext{
${ }^{26}$ The third column denotes the market surprise depicted in the second to last column of Table 2.

${ }^{27}$ On 22.3.2001 the effect was the other way round. The Swiss franc first appreciated and then depreciated.
} 
Table 3.2 summarizes all speeches that significantly affected the CHF/USD rate in at least one of the time windows included in the table. The first column indicates the day and year in which a significant speech was recorded. Entries in columns two to six are based on intraday data. The last three columns display the outcomes obtained using daily data. The second column shows the market movements 30 minutes before the earliest newswire report, followed by the market development in the next 30 minutes, then the interval between 30 and 60 minutes and then between 60 and 120 minutes. The fourth to last column indicates the results in the 24 hours following the first newswire report linked to a speech by an SNB official. The final three columns reflect the market behaviour on the day preceding the interview, the day of, and the day after. This allows us to compare the results obtained with the higher frequency intraday data and to infer whether other causes could have triggered the significant price movements we found. Daily data refer to values at one p.m. (GMT time). The table is broken into panels corresponding to whether a related newswire report was released within (Panel A) or out of (Panel B) trading hours.

As can be gleaned from Panel $A$, we recorded a significant impact on the currency 18 times (out of 68 , see Table 1) (26\%). Some movement occurred between 30 minutes proceeding and 30 minutes following the first related newswire report. As mentioned above, price fluctuations before news arrivals are not to be taken as a sign of informed trading. Among the main reasons for early price movements considered in this study are overlapping events, deficient tracking of broadcasters, imprecise identification of event time, other informational events, and so on. After time-stamping each speech that affected the market we checked the preceding day for significant market movement and found nothing, thus corroborating our results. However, as shown in the last three rows of Panel A, speeches do not have a particular impact on the CHF/USD rate when compared with all other observations included in the sample.

The entries in Panel B refer to speeches that were reported by newswire systems outside of trading hours. We recurred to daily data to capture the market impact at three different points in time, i.e. the day preceding the publication of an interview, the day coinciding with its publication and the day after. From a total of 78 speeches, 12 were found significant on any one of these days. We found a significant impact on the day a speech was given seven times. As can be inferred from the Anova F-statistic and the Variance Ftest, these speeches did affect the return mean and variance of the CHF/USD on communication days. 
Table 3.2 ABOUT HERE

Table 3.3 summarizes the significant reactions of the CHF/USD rate to SNB interviews. According to Panel A, 16 interviews (from a total of 54, see Table 1) were significant at intraday frequency $(30 \%)$. Similar to speeches, interviews mostly affected the CHF/USD rate in the first two time windows. On six occasions we found significant market movement 30 minutes ahead of a related newswire report. Likewise, a significant reaction occurred six times in the 30 minutes following an interview. In three cases there was market fluctuation in the pre- and the post 30-minute interval. In contrast to speeches, the currency market also reacted five times with a delay of one to two hours. This lasting impact of interviews may be due to the fact that this form of communication contains variegated and wideranging contents, whose reading and assimilation can be more time-consuming.

It is also noticeable that the forex market was not subject to significant fluctuations on days prior to an interview. Moreover, given that no lasting impact is detectable on the days when the interviews were reported by newswire systems but is mostly concentrated in one of the time windows, we conclude that the significant effects we found are genuinely linked to the interviews and not attributable to other events taking place beforehand. Both these and the results found for speeches uphold our findings. As follows from the last rows of Panel $A$, interviews do seem to cause market participants to react differently than on other days, 30 to 60 minutes following related newswire reporting. In particular, the variance of the CHF/USD rate increases. The sample statistics show that interviews have some overall significant effect on the forex market. See in particular the Variance F-test.

\section{Table 3.3 ABOUT HERE}

\subsection{Effect on stocks}

Table 4.1 reviews the Swiss stock market's reaction to policy decisions and remarks made at the General Meetings of the Stockholders. Its setup is identical to Table 3.1. The broad picture differs somewhat from our findings about the exchange rate. While policy announcements affected the CHF/USD mostly during the beginning of the sample, 
significant effects on the Swiss equity market ensuing from SNB policy decisions are clustered in the middle of our sample, i.e. from March 2001 to June 2003.

A number of further results emerge upon examination of Table 4.1. First, 9 of 35 events significantly influenced the stock market (26\%). Five came about at scheduled meetings $(22 \%)$ and four at unscheduled meetings (67\%). Unscheduled announcements had the most significant effects. Given that the last unscheduled announcement dates from 6 March 2003, this may explain why both currency market and stock market participants reacted less to SNB policy announcements in recent periods. Second, like the currency market, General Meetings triggered no reaction. Third, the equity market seems to need more time to absorb news related to monetary policy decisions than the foreign currency market. Most of the significant reactions occur within 30 minutes but in some circumstances 45 minutes are necessary. This may be interpreted as a slow price reaction, but it could also be for technical reasons. In particular, we are measuring the equity market reaction by means of the SPI index that includes all equity market capitalisations quoted at the SWX. Thus, the protracted market adjustment may stem from the most illiquid stocks. Fourth, the significant market movement was mostly downward. Fifth, as can be deduced from the statistical tests reported at the end of the table, monetary policy announcements do not appear to influence the stock market differently from other days' news, apart from an increase in the variance of equity prices in the minutes preceding and following an announcement.

\section{TABLE 4.1 ABOUT HERE}

Table 4.2 summarizes significant stock market responses to SNB speeches. According to Panel A, 20 speeches were significant at intraday frequency (29\%). Panel A makes at least two interesting points. First, speeches affect equity prices significantly. This is especially observable in terms of the Variance F-test. Second, a cluster of significant effects is identifiable in the first half of the sample. On two occasions we found a significant market effect both the day before and in the half hour before and the half hour after a speech. This observation suggests that the market was subject to large fluctuations that were not associated with SNB communication but rather with exogenous events. Another point worth 
stressing is the incidence of some market rebounds taking place between the first time window (30 minutes before a speech) and subsequent intraday time windows. By way of example, the equity market switched from a positive price movement half an hour before a speech of 17 September 2001 to a negative reaction in the half hour following it. From the last row of Panel A we can infer that official SNB speeches had a distinct impact on the variance of stock prices directly prior to their reporting by newswire services, and in the two hours following reporting, in comparison with the whole sample of observations.

TABLE 4.2 ABOUT HERE

Table 4.3 summarizes significant effects of interviews on equities. A number of clear results are apparent upon closer examination of the table. First, as can be taken from Panel A, 21 interviews reported during trading hours turn out to have been significant (39\%). Second, interviews seem to have had an effect on equities in the middle of the sample, i.e. from May 2001 to October 2003. Third, if there was any significant market reaction, the effect was visible in more than one intraday time window. The effect was quite regularly spread over the 30-minute windows to the 24-hour window. Most significant effects are found 30 minutes after the interview was reported by newswire systems. Fourth, the stock market tended to react positively to SNB interviews during 2003, whereas in general there was no unidirectional pattern. From the statistical tests at the bottom of Panel $A$ we can see that interviews had a strong and distinct effect on equity prices' variance at all intraday time windows examined.

As can be seen in Panel B, we found significant market movement coinciding with SNB interview-related newswire system reports outside of working hours on 10 occasions (out of 86). In keeping with the findings outlined in Panel $A$, there were clearly fewer market reactions at the beginning and at the end of the sample. Furthermore, the market reacted consistently positively to this form of SNB communication in 2003. Finally, interviews triggered an increase in equities' variance different from other trading days. As already noted in Table 4.1 and 4.2, the variance impact was also remarkable for monetary policy decisions and speeches. We conclude from these observations that SNB communication tends to have a greater impact on the second moment of equities' return distribution than 
on the first moment, a finding that may be interpreted as proof of the heterogeneity in market participants' expectations of risk premia.

Table 4.3 ABOUT HERE

\subsection{Effects on bonds}

When comparing the effect of announcements on the bond market with the other two markets examined in the preceding subsections, it must be noted that the number of observations pertinent to monetary policy announcements available diminishes from 35 to 29. As explained above, this is due to data unavailability for Swiss bond indices for the period 28 November 2002 to 7 November 2003. Thus we have to make do with 19 scheduled announcements, 5 unscheduled announcements and 5 General Meetings.

Table 5.1 clearly shows that, of all assets, bonds are the most sensitive to monetary policy decisions - in line with previous rankings among financial assets suggested in the literature. ${ }^{28}$ This is documented by all the sample tests, supporting the idea of a close link between monetary policy and the bond discount factor that ultimately determines bond values.

Several additional results emerge from Table 5.1. First, not only monetary policy announcements, of which 8 were scheduled and 3 unscheduled but also - in contrast to the other two markets - addresses at the General Meetings, had 3 times as statistically significant effect on bond prices. Second, in contrast to the CHF/USD rate and the stock exchange, the effect of the Swiss monetary authorities is concentrated in the last period of this sample, beginning with the Board's resolution to abandon its expansionary policy course. ${ }^{29}$ Third, bonds reacted to policy decisions with a lag varying from 5 to 30 minutes. In most cases the responses were unidirectional, mainly downward. However, the announcements of the last two monetary policy meetings covered in this paper (15 September and 12 December 2005) were accompanied by an upward movement in bond prices. Finally, judged by all three statistical tests conducted, monetary policy

\footnotetext{
${ }^{28}$ See, for instance, Andersen et al. (2005).

${ }^{29}$ Note, however, that six venues in 2003 are missing.
} 
announcements exerted a particular influence on bond prices, ascertainable in the first 30 minutes after the event, distinguishable from other days.

TABLE 5.1 ABOUT HERE

In Table 5.2 we report the implications of speeches on the bond market. Panel A shows that 41 speeches had an effect on bonds (60\%). On 15 occasions the bond market was affected ahead of newswire reporting. Similarly, 15 speeches led to market reactions within 30 minutes following a connected report. On three occasions we note a significant fluctuation both 30 minutes prior to and 30 minutes subsequent to a newswire. Only once (7 December 2005) did we detect a significant market movement the preceding day as well as a significant fluctuation in the bond market 30 minutes ahead of a speech.

In order to gauge the reaction of bonds to speeches given during business hours, we examined the market on the day preceding a speech, the day of, and the day after (Panel B). Thirteen speeches coincided with a significant market reaction on one of these days. While the market's reaction the following day was positive until mid-June 2003, it has been negative since.

TABLE 5.2 ABOUT HERE

Table 5.3 lists all interviews that significantly affected the bond market. According to Panel A, 31 interviews (57\%) went hand in hand with a significant market reaction in one of the time windows considered - ranging from 30 minutes ahead of the first newswire report to 24 hours after it. On six occasions we detected a movement that preceded a newswire report related to an SNB interview. The bulk, exhibiting a negative market impact, is clustered around September 2002 and February 2003. Interestingly, the market displays only a few 
significant reactions in the 30-60 minute window. Rather, bonds tended to react either with a delay of 30 minutes or with a lag of one to two hours. Similar to speeches, interviews often have a drawn-out effect noticeable even 24 hours following the communication. On four different occasions, bonds fluctuated significantly on the day prior to the publication of an SNB interview that had a significant effect on the bond market the subsequent day. However, in none of these cases was there a significant market fluctuation in the 30 minute window before the interview was reported by the newswire systems. From this we conclude that the market was genuinely reacting to newswire reports about an SNB interview rather than to another, previous event. Significant market movements ahead of a newswire report are hardly attributable to interviews, given that neither their time nor date is public knowledge. From the statistical tests presented at the bottom of Panel $A$, we deduce that bonds in particular respond to SNB interviews with increasing variance and with a delay of thirty minutes.

TABLE 5.3 ABOUT HERE

\subsection{Regression analysis}

The non-parametric approach employed so far allows us to infer the frequency with which central bank communication affects the financial markets. In this section we complement our analysis with a parametric test that summarizes the analysis and allows us to check the robustness of the results. Following Kohn and Sack (2004), we estimated the following regression equation:

$$
\Delta y_{t, k}=\alpha_{0}+\beta_{1} \Delta f f_{t, k}+\eta_{t, k}
$$

where $\Delta \mathrm{y}_{\mathrm{t}, \mathrm{k}}$ is the intraday change in the financial variable on day $\mathrm{t}$ and intraday time $\mathrm{k} . \alpha$ is a constant; $\beta$ captures the effects of the unexpected component of monetary policy decisions, measured by $\Delta \mathrm{ff}$. It is computed from the change in the nearest-to-maturity futures contract of the three-month Libor within the first 20 minutes (for announcements) or 30 minutes (for speeches and interviews) after the first newswire report on SNB communication. The error term, $\eta_{t, k}$, represents any other pricing factors affecting the financial variable, such as revisions of the implicit short-term interest rate path beyond the next three months, term premia, risk premia and all other possible asset-specific value drivers. 
The results are reported in Table 5.4. The results for the coefficient $\beta$, which represents the monetary policy surprise, are reported in the second column. The sign of the coefficient is as expected (with one exception). An (unexpected) interest rate increase tends to strengthen the Swiss franc to the US dollar while it negatively affects stock and bond market value. All three communication forms analyzed in this paper exhibit estimated $\beta$ coefficients that are only weakly significant in statistical terms. By this measure, the strongest reaction is perceptible in the bond market and the weakest in the equity market where only announcements exhibit a statistically significant coefficient. The last column shows what we call the "variance ratio". It represents the ratio of the variance of the error term $\eta_{t, k}$ for each financial variable on communication day $t$ to the variance on all noncommunication days in the sample at the same intraday time k. That is, we contrast the intraday effect of communication days with those days that did not involve any policy announcements, speeches or interviews. Given that equation (1) controls for the direct effect of policy surprises, the residual $\eta_{t, k}$ should genuinely determine whether communication had any effect beyond the short-term policy outlook.

The results show that monetary policy announcements had some effect beyond the contemporaneous policy decisions. The variance of the error term in the regression involving the exchange rate is sizable and statistically significant. Policy announcements also had a sizable and significant effect on the variance ratio of the bond market but no effect on equities' variance ratio. Besides the announcements, only interviews increase the variance ratio. Overall, the results of the regression analysis are essentially in line with the non-parametric analysis. However, these results are based on relatively few observations and thus should be interpreted with due care.

Table 5.4 about here 


\section{Summary}

A number of clear results emerge from our analysis. First, we find that Swiss asset markets react significantly to monetary policy announcements. This finding is similar to previous research on other asset markets. Analyzing monetary policy case by case, we observe that not only some unscheduled monetary policy announcements but also some scheduled decisions moved the markets significantly. Thus, even if the monetary policy framework is highly transparent and substantiated by a high communication frequency, the information delivered at scheduled monetary policy decisions may contain news for market participants.

Second, the reaction to monetary policy announcements was time-variant across the three markets. While the foreign exchange market reacted conspicuously at the beginning of the sample period, coinciding with a restrictive monetary policy, the equity market showed responsiveness in the middle of the sample, concomitant with a very expansionary monetary policy and record-low interest rates. Bonds responded towards the end of sample, a period marked by a gradual "normalization" of interest rates.

Third, a novel contribution of this paper to the literature is that speeches and interviews by central bank officials also affect asset markets. This empirical evidence suggests that market participants are receptive to central bank information. In general, interviews seem to influence the financial markets more than speeches. While the effects on the currency market were relatively modest, both communication forms tended to strongly affect the bond market. Interviews also had a perceptible impact on the stock market.

Fourth, of all the markets, the bond market is clearly the most responsive to all three communication tools considered in this paper. While the sensitivity of bonds to monetary policy announcements has been documented in the literature, we report evidence that bonds in particular also respond significantly to speeches and interviews. Equities display the least reaction of all three markets. One explanation resides in the factors determining the discounted value of these assets. By simply splitting the discount factor into three main components, we can interpret the value drivers as the real interest rate, expected inflation and risk premia. Bonds appear to manifest the closest link with monetary policy since two of the three main ingredients making up the bond discount factor (i.e. real interest rates and expected inflation) largely depend on central bank decisions. Exchange rates are essentially valued in terms of economic fundamentals that, in turn, significantly depend on monetary policy too. On the other hand, discounted equity values may be largely influenced by risk premia. Also, dividend and cash-flow streams are more influenced by corporatespecific issues than monetary policy decisions. This should also explain why equity prices reveal less sensitivity to central bank communication than bonds and exchange rates. 
Fifth, our analysis shows the typical patterns and timing of communication impacts. The strongest effect of policy announcements on the foreign exchange market crops up within 15 minutes. Bonds react within 30 minutes, but mostly between 5 and 15 minutes. Equities are the most sluggish, reacting with a delay of up to 60 minutes. Reactions to speeches and interviews last longer on all three markets and are more difficult to situate. This may be due to technical aspects such as index construction including less liquid assets or the more time-consuming analysis required, in contrast to interest rate decisions. It is also possible that a protracted re-valuation process elicited by monetary policy news is a sign of market participants' heterogeneity. The fact that a price reaction is still visible one or two hours after a news release may also be due to more passive traders. Another plausible explanation for sluggish market responses is that there are many information sources available and that the same news provider may release information updates related to the original news item. Given the possibility that broadcasters release the same news items in a non-synchronised way and/or quote each other within a short period of time, multiple information sources may translate into a longer-lasting impact of news items.

Sixth, as far as speeches and interviews are concerned, we perceive immediate and occasionally even premature market fluctuations with respect to newswire reports. This may be due to the limited number of newswire broadcasters covered in our analysis. By the same token, this could also be traced to the presence of traders actively monitoring and promptly reacting to information flows. A further explanation could be found in the methodological limitations of our event study setup.

Finally, while at the beginning of the sample period it was the currency market that responded most aggressively to SNB communication, in the later period it was the bond market. Monetary policy was continuously loosened from 2001 to 2003, evidenced by a reduction in the three-month Libor from $3.25 \%$ to a trough of $0.25 \%$. It was not until midJune 2004 that a gradual "normalization" of interest rates set in. Hence, it appears that the currency market was more sensitive to communications when interest rates were falling whereas the bond market responded more when interest rates began to rise. Arguably, as short-term interest rates approach the zero lower bound, more interventions on the currency market may be called for. However, this reading of the results is clouded by the lack of data on bond markets from the end of 2002 to the end of 2003. Overall, the interpretation of these findings must not stretch a point. The sample is too short for a comprehensive analysis. 


\section{Conclusions}

Communication provides monetary policy authorities with an effective means of explaining their thinking and decisions. As such, communication is potentially an important avenue for central bankers to disseminate valuable information to investors. This paper adds to the expanding literature on central bank transparency by highlighting the effects of SNB communication on asset markets from 2000 to 2005. We provide evidence for intraday patterns of financial market reactions, suggesting that market participants react promptly to SNB communication. Significant market movement at the time of the earliest news release suggests that traders actively monitor real-time central bank information.

Our results, derived from Swiss financial data, hint at three conclusions. First, a new result borne of our analysis is that speeches and interviews by central bank officials do provide important information to market participants. In line with previous research, we also find that monetary policy announcements have a significant impact on financial assets. Second, a significant market reaction is observable for the bond, equity and foreign currency markets. This result is important in several respects. It shows that market participants pay heed to this form of communication, through which central banks can convey information in a flexible way. Speeches and interviews complement monetary policy announcements in notifying market participants of past, current and future SNB decisions and economic conditions. Overall, they may effectively contribute to enhancing the transparency of a central bank authority. Third, using a new high-frequency database allowed us to accurately analyze market reactions to real-time communication. The bond market is the most responsive to public announcements, followed by the currency market, while the stock exchange is the least reactive. We attribute these diverse reaction patterns to the various relationships between monetary policy and discounted asset values. In this paper we have focused on the use of communication tools and the associated market reactions. Further research could be devoted to the content, the clarity, the length and complexity of central bank communication and its market effects. 


\section{References}

Andersen, T.G., T. Bollerslev, F.X. Diebold and C. Vega. 2005. Real-Time Price Discovery in Stock, Bond and Foreign Exchange Markets. NBER Working Paper 11312, May.

Andersen, T.G., T. Bollerslev, F.X. Diebold and C. Vega. 2003. Micro Effects of Macro Announcements: Real-Time Price Discovery in Foreign Exchange. American Economic Review 93(1): 38-62.

Balduzzi, P., E.J. Elton and T.C. Green. 2001. Economic News and Bond Prices: Evidence from the U.S. Treasury Market. Journal of Financial and Quantitative Analysis 36(4), December: 523-543.

Bell, J. and R. Windle. 2005. Monetary policy news and market reaction to the Inflation Report and MPC Minutes. Bank of England. Quarterly Bulletin, Summer: 169-178.

Bernanke, B. 2004. Fedspeak. Remarks at the Meetings of the American Economic Association, San Diego, California, January 3. available at www.federalreserve.govboarddocs/speeches/2004/200401032/default.htm.

Blinder, A.S. 2006a. Monetary Policy by Committee: Why and How? DNB Working Paper No. 92, February.

Blinder, A. S. 2006b. Monetary Policy Today: Sixteen Questions and about Twelve Answers. Paper prepared for the Banco de España Conference on "Central Banks in the $21^{\text {st }}$ Century," Madrid, June 8-9.

Blinder, A. S. 1998. Central Banking in Theory and Practice. Cambridge MA: MIT Press.

Blinder, A., Ch. Goodhart, Ph. Hildebrand, D. Lipton, Ch. Wyplosz. 2001. How Do Central Banks Talk? Geneva Report on the World Economy 3, ICMB.

Bomfim, A.N. 2003. Pre-announcement Effects, News Effects, and Volatility: Monetary Policy and the Stock Market. Journal of Banking and Finance 27: 133-151.

Chortares, G., D. Stasavage, and G. Sterne. 2002. Does It Pay To Be Transparent? International Evidence from Central Bank Forecasts. Federal Reserve Bank of St. Louis Review 84(4), July/August: 99-117.

Clare, A. and R. Courtenay. 2001. What can we learn about monetary policy transparency from financial market data? Deutsche Bundesbank Discussion paper 06/01. 
Clare, A. and R. Courtenay. 2000. Financial market reactions to interest rate announcements and macroeconomic data releases. Bank of England Quarterly Bulletin, August.

Cook, T. and T. Hahn. 1989. The effect of changes in the Federal funds rate target on market interest rates in the 1979s. Journal of Monetary Economics 24: 331-351.

Ederington, L.H. and J.H. Lee. 1995. The Short-Run Dynamics of the Price Adjustment to New Information. Journal of Financial and Quantitative Analysis 30(1), March: 117-134.

Ederington, L.H. and J.H. Lee. 1993. How Markets Process Information: News Releases and Volatility. Journal of Finance 48: 1161-1191.

Edison, H. 1997. The Reaction of Exchange Rates and Interest Rates to News Releases. International Journal of Finance and Economics 2: 87-100.

Ehrmann, M. and M. Fratzscher. 2005a. Central Bank Communication: Different Strategies, Same Effectiveness? ECB Working Paper No. 488.

Ehrmann, M. and M. Fratzscher. 2005b. The Timing of Central Bank Communication. ECB Working Paper No. 565, December.

Ehrmann, M. and M. Fratzscher. 2005c. How Should Central Banks Communicate? ECB Working Paper No. 557, November.

Ehrmann, M. and M. Fratzscher. 2004. Transparency, Disclosure and the Federal Reserve. European Central Bank. Mimeo.

Fair, R.C. 2003. Shock Effects on Stocks, Bonds, and Exchange rates. Journal of International Money and Finance 22: 307-341.

Faust, J., J.H. Rogers, S.-Y.B. Wang and J.W. Wright. 2003. The High-Frequency Response of Exchange Rates and Interest Rates to Macroeconomic Announcements. Board of Governors of the Federal Reserve System International Finance Discussion Paper No. 784, October.

Fleming, M.J. and J. Lopez. 1999. Heat Waves, Meteor Showers, and Trading Volume: An Analysis of Volatility Spillovers in the U.S. Treasury Market. Federal Reserve Bank of New York Staff Report no. 82, July.

Fratzscher, M. 2004. Communication and exchange rate policy. ECB Working Paper No. 363, May.

Geraats, P.M. 2002. Central Bank Transparency. Economic Journal 112, November: F532F565. 
Geraats, P.M., S.C.W. Eijffinger and C.A.B. van der Cruijsen. 2006. Does Central Bank Transparency Reduce Interest Rates? CEPR Discussion Paper No. 5526, March.

Gerlach-Kristen, P. 2004. Is the MPC's Voting Record Informative about Future UK Monetary Policy? Scandinavian Journal of Economics 106(2): 299-313.

Goldberg, L. and D. Leonard. 2003. What Moves Sovereign Bond Markets? The Effects of Economic News on U.S. and German Yields. Federal Reserve Bank of New York Current Issues in Economic and Finance 9(9).

Gürkaynak, R.S, B. Sack and E.T. Swanson. 2005a. The Sensitivity of Long-Term Interest Rates to Economic News: Evidence and Implications for Macroeconomic Models. American Economic Review 95(1), March: 425-436.

Gürkaynak, R.S, B. Sack and E.T. Swanson. 2005b. Do Actions Speak Louder Than Words? The Response of Asset Prices to Monetary Policy Actions and Statements. International Journal of Central Banking 1(1), May: 55-93.

Gürkaynak, R., A.T. Levin, and E.T. Swanson. 2005. Inflation Targeting and the Anchoring of Long-Run Inflation Expectations: International Evidence from Daily Bond Yield Data. Paper prepared for the Sveriges Riksbank conference in June 2005 on "Inflation targeting: implementation, communication and effectiveness."

Hardouvelis, G. 1988. Economic News, Exchange Rates and Interest Rates. Journal of International Money and Finance 7: 23-35.

Jansen, D-J. and J. De Haan. 2005. Talking heads: the effects of ECB statements on the euro-dollar exchange rate. Journal of International Money and Finance 24: 343-361.

Jordan, T.J. and E. Rossi. 2007. Communication in Monetary Policy: Experiences of the Swiss National Bank. Mimeo.

Kohn, D.L. and B.P. Sack. 2004. Central Bank Talk: Does It Matter and Why? In Macroeconomics, Monetary Policy, and Financial Stability. Ottawa: Bank of Canada.

Loderer, C. and M.-A. Mittermayer. 2006. America and the Swiss Stock Exchange: An Intraday Analysis. Swiss Journal of Economics and Statistics 142(1): 79-114.

Poitras, M. 2004. The Impact of Macroeconomic Announcements on Stock Prices: In Search of State Dependence. Southern Economic Journal 70: 549-565.

Reeves, R. and M. Sawicki. 2005. Do financial markets react to Bank of England communication? Bank of England Quarterly Bulletin, Winter: 431-439. 
Rigobon, R. and B. Sack. 2006. Noisy Macroeconomic Announcements, Monetary Policy, and Asset Prices. NBER Working Paper 12420, August.

Roth, J.-P. 2006. No News: Good News. Transparency and communication in monetary policy. Speech delivered at the Annual Meeting of the European Business Press, 16 June 2006.

Roth, J.-P. 2002. Ist eine Notenbank für Überraschungen gut? Referat vor der StatistischVolkswirtschaftlichen Gesellschaft, Basel, 25.3.2002.

Rich, G. 2003. Swiss Monetary Targeting 1974-1996: The Role of Internal Policy Analysis. ECB Working Paper No. 236, June.

Swanson, E.T. 2006. Have Increases in Federal Reserve Transparency Improved Private Sector Interest Rate Forecasts? Journal of Money, Credit, and Banking 38(3), April: 791-819.

Van der Cruijsen, C. and M. Demertzis. 2005. The Impact of Central Bank Transparency on Inflation Expectations. DNB Working Paper No. 031/2005, March.

Wilhelmsen, B.-R. and A. Zaghini. 2005. Monetary Policy Predictability in the Euro Area - An International Comparison. ECB Working Paper No. 504, July.

Woodford, M. 2005. Central Bank Communication and Policy Effectiveness. In The Greenspan Era: Lessons for the Future. Federal Reserve Bank of Kansas City Symposium, Jackson Hole, Wyoming, August 25.27.

Woodford, M. 2003. Interest and Prices: Foundations of a Theory of Monetary Policy. Princeton University Press: Princeton.

Zebedee, A. A., E. Bentzen, P.R. Hansen and A. Lunde. 2005. The Greenspan Effect on Equity Markets: An Intraday Examination of US Monetary Policy Announcements. Mimeo. 
Table 1: Communication items

\begin{tabular}{|c|c|c|c|c|c|c|}
\hline \multirow[b]{2}{*}{ Panel A: Summary } & \multicolumn{2}{|c|}{$\begin{array}{l}\text { Monetary policy } \\
\text { announcements }\end{array}$} & \multicolumn{2}{|l|}{ Speeches } & \multicolumn{2}{|l|}{ Interviews } \\
\hline & Number & Rel. Freq. & Number & Rel. Freq. & Number & Rel. Freq. \\
\hline All & 36 & $100 \%$ & 146 & $100 \%$ & 177 & $100 \%$ \\
\hline Within trading hours (from 9 to 17 ) & 35 & $97 \%$ & 68 & $47 \%$ & 54 & $30 \%$ \\
\hline Off market & 1 & $3 \%$ & 78 & $53 \%$ & 86 & $49 \%$ \\
\hline During weekends & 0 & $0 \%$ & 0 & $0 \%$ & 37 & $21 \%$ \\
\hline \multicolumn{7}{|l|}{ Panel B: By year } \\
\hline 2000 & - & - & 14 & $10 \%$ & 26 & $14 \%$ \\
\hline 2001 & - & - & 13 & $9 \%$ & 34 & $19 \%$ \\
\hline 2002 & - & - & 31 & $21 \%$ & 38 & $22 \%$ \\
\hline 2003 & - & - & 23 & $16 \%$ & 38 & $22 \%$ \\
\hline 2004 & - & - & 29 & $20 \%$ & 21 & $12 \%$ \\
\hline 2005 & - & - & 36 & $24 \%$ & 20 & $11 \%$ \\
\hline
\end{tabular}


Table 2: SNB Monetary policy announcements

\begin{tabular}{|c|c|c|c|c|c|}
\hline Date & Issuance time & Event & $\begin{array}{c}\text { New mid-point } \\
\text { target }\end{array}$ & Surprise & $t$-stat \\
\hline 20.01.2000 & 09:31 & Unscheduled & 2 & $0.018^{*}$ & 1.94 \\
\hline 03.02 .2000 & $13: 55$ & Unscheduled & 2.25 & $0.067^{* * *}$ & 7.12 \\
\hline 23.03 .2000 & $14: 00$ & Scheduled & 3 & $0.054 * * *$ & 6.04 \\
\hline 28.04 .2000 & $10: 00$ & General Meeting & 3 & 0.009 & 0.98 \\
\hline 15.06 .2000 & 08:50 & Scheduled & 3.5 & 0.003 & 0.33 \\
\hline 14.09 .2000 & $14: 15$ & Scheduled & 3.5 & -0.003 & 0.33 \\
\hline 08.12 .2000 & $09: 45$ & Scheduled & 3.5 & 0 & 0.00 \\
\hline 22.03 .2001 & $14: 00$ & Scheduled & 3.25 & 0.003 & 0.38 \\
\hline 20.04.2001 & $10: 00$ & General Meeting & 3.25 & -0.006 & 0.71 \\
\hline 14.06.2001 & $09: 30$ & Scheduled & 3.25 & 0.006 & 0.70 \\
\hline 17.09.2001 & $17: 43$ & Unscheduled & 2.75 & NA & NA \\
\hline 24.09.2001 & $14: 00$ & Unscheduled & 2.25 & $-0.045^{* * *}$ & 5.08 \\
\hline 07.12 .2001 & $09: 45$ & Scheduled & 1.75 & 0 & 0.00 \\
\hline 21.03.2002 & $14: 00$ & Scheduled & 1.75 & $0.025^{* * *}$ & 2.80 \\
\hline 26.04 .2002 & $10: 00$ & General Meeting & 1.75 & 0.019 ** & 2.10 \\
\hline 02.05 .2002 & $11: 40$ & Unscheduled & 1.25 & $-0.016^{\star}$ & 1.74 \\
\hline 14.06 .2002 & 09:30 & Scheduled & 1.25 & -0.008 & 0.88 \\
\hline 26.07.2002 & $13: 00$ & Unscheduled & 0.75 & $-0.178 * * *$ & 20.02 \\
\hline 19.09.2002 & $14: 00$ & Scheduled & 0.75 & $0.029 * * *$ & 3.26 \\
\hline 13.12.2002 & $09: 45$ & Scheduled & 0.75 & 0 & 0.00 \\
\hline 06.03 .2003 & $13: 51$ & Unscheduled & 0.25 & $-0.474^{* * *}$ & 53.22 \\
\hline 20.03.2003 & $14: 00$ & Scheduled & 0.25 & 0 & 0.00 \\
\hline 25.04 .2003 & $10: 00$ & General Meeting & 0.25 & 0 & 0.00 \\
\hline 13.06 .2003 & $09: 30$ & Scheduled & 0.25 & $0.08^{* * *}$ & 8.99 \\
\hline 18.09.2003 & $14: 00$ & Scheduled & 0.25 & $-0.087^{* * *}$ & 9.77 \\
\hline 12.12 .2003 & $09: 45$ & Scheduled & 0.25 & 0 & 0.00 \\
\hline 18.03.2004 & $14: 00$ & Scheduled & 0.25 & 0 & 0.00 \\
\hline 30.04 .2004 & $10: 00$ & General Meeting & 0.25 & $-0.057^{* * *}$ & 6.42 \\
\hline 17.06 .2004 & $09: 28$ & Scheduled & 0.5 & $-0.057^{* * *}$ & 6.42 \\
\hline 16.09 .2004 & $13: 58$ & Scheduled & 0.75 & -0.011 & 1.23 \\
\hline 16.12 .2004 & $09: 30$ & Scheduled & 0.75 & $-0.067 * * *$ & 7.49 \\
\hline 17.03.2005 & $13: 59$ & Scheduled & 0.75 & -0.024 & 2.74 \\
\hline 29.04 .2005 & $10: 00$ & General Meeting & 0.75 & 0.013 & 1.49 \\
\hline 16.06.2005 & 09:29 & Scheduled & 0.75 & 0 & 0.00 \\
\hline 15.09 .2005 & $13: 59$ & Scheduled & 0.75 & $-0.026^{* * *}$ & 2.92 \\
\hline 15.12 .2005 & $09: 29$ & Scheduled & 1 & -0.01 & 1.10 \\
\hline
\end{tabular}


Table 3.1: Foreign exchange market reactions to monetary policy announcements

\begin{tabular}{|c|c|c|c|c|c|c|c|c|}
\hline Date & $S / U^{*}$ & Surprise & $\begin{array}{l}15 \text { min } \\
\text { before }\end{array}$ & 5 min after & $\begin{array}{c}\text { From } 5 \text { to } \\
15 \mathrm{~min}\end{array}$ & $\begin{array}{c}\text { From } 15 \text { to } \\
30 \mathrm{~min}\end{array}$ & $\begin{array}{c}\text { From } 30 \text { to } \\
45 \mathrm{~min}\end{array}$ & $\begin{array}{c}\text { From } 45 \text { to } \\
60 \mathrm{~min}\end{array}$ \\
\hline 20.01.2000 & U & $0.018^{*}$ & -0.0011 & 0.0003 & -0.0002 & $0.0034 * *$ & -0.0005 & 0.0016 \\
\hline 03.02 .2000 & $U$ & $0.067^{* * *}$ & 0.0012 & $0.0018^{* *}$ & $-0.0046^{* * *}$ & 0.0005 & $-0.0026^{*}$ & 0.0012 \\
\hline 23.03.2000 & $S$ & $0.054^{* * *}$ & 0.0005 & $-0.0039 * * *$ & $-0.0025^{*}$ & -0.0005 & -0.0011 & -0.0003 \\
\hline 28.04 .2000 & G & 0.009 & 0.0012 & 0.0006 & -0.0002 & -0.0011 & 0.0001 & -0.0014 \\
\hline 15.06 .2000 & $S$ & 0.003 & -0.0008 & $0.0018^{* *}$ & 0.002 & 0.001 & 0.0014 & -0.0007 \\
\hline 14.09 .2000 & $S$ & -0.003 & 0.0029 & 0.0008 & 0.0003 & 0.0007 & 0.0013 & 0.0016 \\
\hline 08.12 .2000 & $\mathrm{~S}$ & 0 & 0.0014 & $0.0036 * * *$ & -0.0009 & -0.0002 & -0.0006 & 0.0001 \\
\hline 22.03.2001 & $S$ & 0.003 & 0.001 & $-0.0022^{* *}$ & $0.0026^{* *}$ & -0.0022 & 0.0019 & $0.0026^{*}$ \\
\hline 20.04.2001 & G & -0.006 & 0.0004 & 0.0009 & 0.0006 & 0.0002 & 0.0006 & -0.0004 \\
\hline 14.06 .2001 & $S$ & 0.006 & -0.0006 & -0.0009 & 0.0006 & 0 & -0.0009 & 0.0002 \\
\hline 24.09.2001 & $U$ & $-0.045^{* * *}$ & 0.0001 & $0.0021^{* *}$ & 0.0010 & 0.0019 & -0.0009 & -0.0006 \\
\hline 07.12 .2001 & $S$ & 0 & 0.0007 & 0.0002 & 0.0006 & 0.0001 & 0.0003 & -0.0001 \\
\hline 21.03.2002 & $S$ & $0.025^{* * *}$ & -0.0001 & -0.0008 & 0.0005 & 0.0008 & 0.001 & -0.0005 \\
\hline 26.04.2002 & G & $0.019 * *$ & 0.0023 & -0.0003 & -0.0006 & 0.0011 & 0.0001 & -0.0002 \\
\hline 02.05 .2002 & $U$ & $-0.016^{*}$ & 0.0023 & -0.0002 & 0.0007 & 0.0000 & 0.0006 & -0.0002 \\
\hline 14.06 .2002 & $S$ & -0.008 & 0.0012 & -0.0005 & 0.0003 & 0.0012 & -0.001 & 0.0004 \\
\hline 26.07.2002 & $U$ & $-0.178^{* * *}$ & -0.0006 & $0.0027^{* *}$ & -0.0004 & 0.0013 & -0.0001 & -0.0005 \\
\hline 19.09.2002 & $S$ & $0.029 * * *$ & 0.0009 & 0 & -0.0012 & 0.0011 & -0.0016 & 0.0004 \\
\hline 13.12 .2002 & $S$ & 0 & 0 & -0.0003 & 0 & -0.0002 & 0.0002 & -0.0018 \\
\hline 06.03 .2003 & $U$ & $-0.474 * * *$ & 0.0000 & 0.0014 & 0.0012 & -0.0009 & -0.0024 & -0.0010 \\
\hline 20.03.2003 & $S$ & 0 & 0.0001 & 0.0005 & 0.0017 & 0 & -0.0003 & -0.0013 \\
\hline 25.04 .2003 & G & 0 & -0.0007 & 0.0007 & -0.0003 & 0.0014 & 0.0014 & -0.0009 \\
\hline 13.06 .2003 & $S$ & $0.08^{* * *}$ & -0.0008 & 0.0006 & $-0.0027^{* *}$ & 0.0003 & 0.0016 & -0.0008 \\
\hline 18.09 .2003 & $S$ & $-0.087^{* * *}$ & 0.0004 & -0.0001 & -0.0003 & -0.0006 & 0.0005 & 0.0001 \\
\hline 12.12.2003 & $S$ & 0 & -0.0002 & 0.0001 & 0.0002 & 0.0015 & -0.0008 & -0.0007 \\
\hline 18.03 .2004 & $S$ & 0 & 0.0002 & 0.0002 & -0.0008 & -0.0006 & 0.0006 & 0 \\
\hline 30.04 .2004 & G & $-0.057^{* * *}$ & 0.0001 & 0.0002 & 0.0018 & -0.001 & 0.0007 & -0.0001 \\
\hline 17.06 .2004 & $S$ & $-0.057^{* * *}$ & -0.0012 & $-0.019 * *$ & $-0.0033^{* *}$ & -0.0013 & 0.0000 & 0.0004 \\
\hline 16.09 .2004 & $S$ & -0.011 & 0.0005 & 0.0002 & 0.0006 & -0.0005 & -0.0005 & -0.0002 \\
\hline 16.12 .2004 & $S$ & $-0.067^{* * *}$ & -0.0001 & 0.0006 & 0.0007 & 0.0006 & -0.0005 & 0.0006 \\
\hline 17.03 .2005 & $S$ & -0.024 & 0.0003 & 0.0013 & 0.0006 & 0.0009 & 0.0017 & -0.0006 \\
\hline 29.04 .2005 & G & 0.013 & 0.0001 & -0.0005 & 0.0008 & -0.0003 & 0.0003 & -0.0001 \\
\hline 16.06 .2005 & $S$ & -0.001 & -0.0004 & -0.0001 & -0.0002 & 0.0002 & -0.0003 & -0.0006 \\
\hline 15.09 .2005 & $S$ & $-0.026^{* * *}$ & -0.0008 & 0.0011 & 0.0005 & 0.0014 & 0.0006 & -0.0006 \\
\hline 15.12.2005 & $\mathrm{S}$ & -0.01 & -0.0002 & 0.0005 & 0.001 & -0.0009 & -0.0015 & 0.0009 \\
\hline \multicolumn{9}{|c|}{ All announcements } \\
\hline Anova F-stat & & $622 * * *$ & $6.11^{* *}$ & $15.87^{* * *}$ & $51.47^{* * *}$ & $7.66^{* * *}$ & 0.18 & 0.05 \\
\hline Med. Chi-sq. & & $3.25^{* *}$ & 2.35 & $3.28 * *$ & $10.35^{* * *}$ & $3.47^{\star}$ & 0.27 & 2.32 \\
\hline Variance F-test & & $4229 * * *$ & 1.14 & $9.49 * * *$ & $8.24^{* * *}$ & 1.36 & 1.47 & 1.01 \\
\hline \multicolumn{9}{|l|}{ Scheduled only } \\
\hline Anova F-stat & & $161^{* * *}$ & $4.86^{* *}$ & $3.54^{*}$ & $54.63 * * *$ & $2.79 *$ & 2.46 & 0.09 \\
\hline Med. Chi-sq. & & $2.78^{*}$ & 1.69 & 1.42 & $7.78^{* * *}$ & 1.7 & 1.69 & 1.69 \\
\hline Variance F-test & & $816^{* * *}$ & 1.03 & $8.93 * * *$ & $6.69 * * *$ & 1.01 & 1.14 & 1.07 \\
\hline \multicolumn{9}{|c|}{ No unscheduled, no general meetings } \\
\hline Anova F-stat & & $188^{* * *}$ & 2.49 & $3.30^{*}$ & $35.3 * * *$ & $2.86^{*}$ & 0.83 & 0.06 \\
\hline Med. Chi-sq. & & $2.9^{*}$ & 0.67 & 0.99 & $5.28 * *$ & 2.13 & 0.05 & 0.04 \\
\hline Variance F-test & & $1345^{* * *}$ & 1.01 & $10.92^{* * *}$ & $7.72 * * *$ & 1.02 & 1.33 & 1.07 \\
\hline
\end{tabular}

* S means scheduled monetary policy decisions; U means unscheduled monetary policy decisions; $G$ stands for General Meeting. 
Table 3.2: Foreign exchange market reactions to official speeches

Panel A: within trading hours

\begin{tabular}{|c|c|c|c|c|c|c|c|c|}
\hline date & $\begin{array}{l}30 \text { min } \\
\text { before }\end{array}$ & $\begin{array}{l}30 \text { min } \\
\text { after }\end{array}$ & $\begin{array}{c}\text { from } 30 \text { to } \\
60 \mathrm{~min}\end{array}$ & $\begin{array}{c}\text { from } 1 \mathrm{~h} \text { to } \\
2 \mathrm{~h}\end{array}$ & $\begin{array}{c}\text { within } 24 \\
\text { hours }\end{array}$ & day before & same day & day after \\
\hline 03.04 .2000 & $-0.0037 * * *$ & -0.0009 & - & - & 0.0062 & -0.0054 & 0.0000 & 0.0000 \\
\hline 12.05 .2000 & -0.0019 & $-0.0026^{* *}$ & 0.0006 & -0.0016 & -0.0102 & 0.0000 & 0.0068 & -0.0150 ** \\
\hline 14.09.2001 & -0.0006 & $-0.0022^{*}$ & $-0.0023^{*}$ & -0.0016 & $-0.0265^{* * *}$ & -0.0046 & -0.0081 & 0.0000 \\
\hline 17.09.2001 & -0.0026 ** & $-0.0053^{* * *}$ & 0.0007 & 0.0019 & 0.0061 & -0.0081 & $-0.0288 * * *$ & 0.0098 \\
\hline 22.10 .2001 & $0.0035 * * *$ & 0.0014 & - & - & 0.0048 & 0.0021 & 0.0025 & 0.0116 * \\
\hline 06.03 .2002 & $-0.0028 * *$ & 0.0008 & - & - & -0.0089 & -0.0057 & 0.0000 & $-0.0135^{* *}$ \\
\hline $18.06 .2002^{a}$ & -0.0004 & -0.0007 & 0.0002 & -0.0008 & $-0.0123^{*}$ & -0.0011 & -0.0033 & -0.0089 \\
\hline 23.07 .2002 & $0.0024^{*}$ & $0.0022 *$ & $-0.0023^{*}$ & 0.0004 & -0.0007 & -0.0011 & $0.0194 * * *$ & 0.0002 \\
\hline 21.05 .2003 & 0.001 & 0.0011 & 0.0002 & $-0.005^{* * *}$ & 0.0004 & 0.0059 & -0.0092 & 0.0070 \\
\hline $05.06 .2003^{a}$ & $-0.0035^{* * *}$ & $-0.0033^{* * *}$ & 0.0005 & -0.0015 & 0.0088 & 0.0054 & 0.0077 & $-0.0122^{*}$ \\
\hline 26.06 .2003 & $0.003^{* *}$ & 0.0002 & -0.0014 & 0.0017 & 0.0086 & 0.0012 & 0.0071 & 0.0129 * \\
\hline 27.10 .2003 & 0 & -0.0001 & -0.0014 & $0.0033^{*}$ & 0.0039 & 0.0044 & 0.0019 & 0.0025 \\
\hline 05.12 .2003 & 0.001 & -0.0005 & 0.0006 & -0.002 & $-0.013^{*}$ & 0.0010 & 0.0004 & $-0.0148 * *$ \\
\hline 07.05 .2004 & 0.0005 & 0.0002 & -0.0002 & -0.0002 & $0.0138 * *$ & 0.0002 & 0.0094 & 0.0090 \\
\hline 18.11 .2004 & -0.0009 & -0.0003 & $0.0024^{*}$ & & -0.0049 & -0.0018 & -0.0087 & 0.0000 \\
\hline 29.11.2004 & - & -0.0004 & $-0.0023 *$ & 0.002 & -0.003 & 0.0020 & -0.0024 & -0.0021 \\
\hline 29.08 .2005 & 0.0002 & -0.0007 & - & - & $0.0129 *$ & -0.0039 & -0.0004 & $0.0110^{*}$ \\
\hline 29.11 .2005 & 0.0008 & -0.0002 & -0.0002 & $0.0031 *$ & 0.0035 & 0.0022 & -0.0101 & 0.0041 \\
\hline$\%$ signif. & $10 \%$ & $7 \%$ & $6 \%$ & $4 \%$ & $7 \%$ & $0 \%$ & $3 \%$ & $10 \%$ \\
\hline Anova F-stat & 0.89 & 0.04 & 0.06 & 0.07 & 0.05 & 0.37 & 0.30 & 0.33 \\
\hline Med. Chi-sq. & 0.68 & 0.68 & 0.11 & 0.35 & 0.39 & 0.06 & 0.53 & 0.01 \\
\hline Var. F-test & 1.14 & 1.11 & $1.38^{*}$ & 1.25 & 1.34 & 1.06 & 1.12 & 1.35 \\
\hline
\end{tabular}

Panel B: off market

\begin{tabular}{|c|c|c|c|}
\hline date & day before & same day & day after \\
\hline 28.02 .2000 & 0.0066 & $0.0179 * * *$ & -0.0070 \\
\hline 21.12 .2000 & -0.0010 & $-0.0126^{*}$ & -0.0009 \\
\hline 07.03 .2002 & 0.0000 & $-0.0135^{* *}$ & -0.0023 \\
\hline 21.06 .2002 & -0.0061 & -0.0091 & $-0.0120 *$ \\
\hline 25.06 .2002 & $-0.0120 *$ & 0.0067 & $-0.0182 * * *$ \\
\hline 17.03 .2003 & $0.0121^{*}$ & -0.0046 & $0.0219 * * *$ \\
\hline 31.03 .2003 & -0.0007 & $-0.0137 * *$ & -0.0037 \\
\hline 16.06 .2003 & 0.0057 & $-0.0124^{*}$ & 0.0054 \\
\hline 22.10 .2004 & -0.0048 & 0.0017 & $-0.0157 * *$ \\
\hline 05.01 .2005 & $0.0134^{* *}$ & $0.0135^{* *}$ & 0.0049 \\
\hline 22.02 .2005 & -0.0008 & $-0.0122^{*}$ & -0.0047 \\
\hline 10.06 .2005 & 0.0063 & 0.0020 & $0.0146^{* *}$ \\
\hline$\%$ signif. & $4 \%$ & $9 \%$ & $6 \%$ \\
\hline Anova F-stat & 0.84 & $4.78^{* *}$ & 0.72 \\
\hline Med. Chi-sq. & 0.02 & 1.12 & 1.51 \\
\hline Var. F-test & 1.14 & $2.95^{* *}$ & $2.79 * *$ \\
\hline
\end{tabular}

${ }^{a}$ Overlapping events: this speech was preceded by an interview. 
Table 3.3: Foreign exchange market reactions to interviews

Panel A: within trading hours

\begin{tabular}{|c|c|c|c|c|c|c|c|c|}
\hline date & $\begin{array}{l}30 \text { min } \\
\text { before }\end{array}$ & $\begin{array}{c}30 \text { min } \\
\text { after }\end{array}$ & $\begin{array}{c}\text { from } 30 \text { to } \\
60 \mathrm{~min}\end{array}$ & $\begin{array}{c}\text { from } 1 \mathrm{~h} \text { to } \\
2 \mathrm{~h}\end{array}$ & $\begin{array}{c}\text { within } 24 \\
\text { hours }\end{array}$ & day before & same day & day after \\
\hline 02.03 .2000 & -0.0029 & $0.0004 * *$ & 0.0001 & 0.0000 & 0.0065 & 0.0067 & -0.0027 & 0.008 \\
\hline 31.08 .2000 & -0.0012 & 0.0033 & $0.0016^{* * *}$ & 0.0002 & 0.0066 & $0.016^{* *}$ & -0.0055 & 0.0058 \\
\hline 18.01.2001 & -0.0006 & -0.0016 & -0.0044 & $-0.0001^{* * *}$ & -0.0097 & 0.0034 & -0.0023 & $-0.0126^{*}$ \\
\hline 10.05 .2001 & 0.0015 & $0.00293 * *$ & 0.0014 & $0.0034^{*}$ & 0.0090 & 0.0026 & 0 & -0.0039 \\
\hline 21.09 .2001 & 0.0000 & $-0.0087^{* * *}$ & 0.0010 & -0.0018 & 0.0047 & -0.0043 & $-0.0136 * *$ & $0.0136^{* *}$ \\
\hline 04.03 .2002 & 0.0000 & -0.0001 & 0.0006 & $-0.0030 *$ & -0.0058 & -0.0038 & 0.0063 & -0.0057 \\
\hline $23.07 .2002^{\mathrm{a}}$ & $0.0022^{*}$ & $-0.0030 * *$ & 0.0000 & 0.0001 & -0.0038 & -0.0011 & $0.0194 * * *$ & 0.0002 \\
\hline 27.01 .2003 & 0.0005 & 0.0008 & 0.0002 & $0.0051^{* * *}$ & 0.0080 & -0.0046 & -0.0069 & 0 \\
\hline 02.04 .2003 & $0.0033 * * *$ & 0.0009 & -0.0006 & 0.0015 & 0.0073 & -0.0037 & 0.0103 & 0.0069 \\
\hline 07.04 .2003 & $-0.0023^{*}$ & 0.0009 & 0.0020 & -0.0005 & -0.0088 & 0.0047 & $0.0151^{* *}$ & -0.0099 \\
\hline 05.06 .2003 & $-0.0032 * * *$ & $-0.0037^{* * *}$ & $-0.0044 * * *$ & -0.0012 & -0.0076 & 0.0054 & 0.0077 & $-0.0122^{*}$ \\
\hline 18.06 .2003 & 0.0007 & 0.0004 & 0.0014 & $0.0032 *$ & $0.0157^{* *}$ & 0.0054 & 0.0068 & $0.0156^{* *}$ \\
\hline 21.08 .2003 & 0.0014 & 0.0006 & 0.0000 & 0.0009 & $0.0121^{*}$ & -0.0039 & 0.0061 & 0.0092 \\
\hline 22.10 .2003 & 0.0007 & -0.0003 & 0.0013 & 0.0000 & $-0.0151^{* *}$ & 0.0042 & -0.0053 & $-0.0143^{* *}$ \\
\hline 29.01 .2004 & $-0.0033 * * *$ & $-0.0045^{* * *}$ & 0.0010 & 0.0016 & $0.0122^{*}$ & -0.0094 & 0.0056 & 0.0086 \\
\hline 07.04 .2004 & $-0.0028 * *$ & -0.0012 & 0.0010 & -0.0008 & $-0.0126^{*}$ & 0.0041 & -0.0075 & -0.0097 \\
\hline$\%$ signif. & $11 \%$ & $11 \%$ & $2 \%$ & $11 \%$ & $9 \%$ & $2 \%$ & $6 \%$ & $7 \%$ \\
\hline Anova F-stat & 0.31 & 0.20 & $2.67 *$ & 1.29 & 0.05 & 0.48 & 1.41 & 0.55 \\
\hline Med. Chi-sq. & 0.71 & 0.71 & $3.73^{*}$ & 0.38 & 0.09 & 0.24 & 0.01 & 0.58 \\
\hline Var. F-test & 1.20 & $2.16^{* * *}$ & 1.19 & 1.23 & 1.19 & 1.01 & 1.10 & 1.18 \\
\hline
\end{tabular}

Panel B: off market

\begin{tabular}{lccc} 
date & day before & same day & day after \\
\hline 12.01 .2001 & 0.0022 & -0.0054 & $0.0147^{* *}$ \\
19.01 .2001 & -0.0023 & $-0.0126^{*}$ & $0.0183^{* *}$ \\
27.04 .2001 & -0.004 & -0.0036 & $0.0127^{*}$ \\
09.10 .2001 & -0.0097 & 0.0027 & $0.0111^{*}$ \\
28.01 .2002 & 0.003 & $0.0159^{* *}$ & 0.0015 \\
29.01 .2003 & 0.009 & -0.009 & $0.0124^{*}$ \\
04.03 .2003 & -0.0055 & $-0.0113^{*}$ & -0.006 \\
18.03 .2003 & -0.0046 & $0.0219^{* *}$ & -0.0017 \\
28.05 .2004 & -0.0024 & $-0.0164^{* *}$ & 0 \\
24.10 .2004 & & 0 & $-0.0157^{*}$ \\
& & & \\
\% signif. & $0 \%$ & $5 \%$ & $5 \%$ \\
Anova F-stat & 0.04 & 0.13 & 0.01 \\
Med. Chi-sq. & 0.08 & 2.53 & 2.54 \\
Var. F-test & $1.52^{* *}$ & 1.13 & $1.35^{*}$ \\
\hline
\end{tabular}

${ }^{a}$ Overlapping events: this interview was preceded by a speech 
Table 4.1: Swiss equity market reactions to monetary policy announcements

\begin{tabular}{|c|c|c|c|c|c|c|c|c|}
\hline Date & $S / U^{*}$ & Surprise & $\begin{array}{l}15 \text { min } \\
\text { before }\end{array}$ & 5 min after & $\begin{array}{c}\text { From } 5 \text { to } \\
15 \mathrm{~min} \\
\end{array}$ & $\begin{array}{c}\text { From } 15 \text { to } \\
30 \mathrm{~min}\end{array}$ & $\begin{array}{c}\text { From } 30 \text { to } \\
45 \mathrm{~min}\end{array}$ & $\begin{array}{c}\text { From } 45 \text { to } \\
60 \mathrm{~min}\end{array}$ \\
\hline 20.01 .2000 & $U$ & $0.018^{*}$ & 0.0002 & -0.0003 & -0.0001 & -0.0012 & -0.0002 & $-0.0039^{*}$ \\
\hline 03.02 .2000 & $U$ & $0.067 * * *$ & 0.0012 & -0.0006 & 0.0019 & -0.0003 & 0.0002 & 0.0004 \\
\hline 23.03 .2000 & $S$ & $0.054 * * *$ & -0.001 & 0.0001 & 0.0003 & 0.0013 & -0.002 & -0.0007 \\
\hline 28.04 .2000 & G & 0.009 & -0.0013 & 0.0002 & 0.0003 & 0.0011 & -0.0007 & -0.0001 \\
\hline 15.06 .2000 & $S$ & 0.003 & 0 & -0.0006 & 0.0018 & 0.0007 & -0.0005 & -0.0001 \\
\hline 14.09 .2000 & $S$ & -0.003 & -0.0001 & 0.0001 & 0.0015 & 0.0005 & 0.0012 & 0.0013 \\
\hline 08.12 .2000 & $S$ & 0 & 0.0012 & 0.0005 & 0.0007 & 0.0021 & -0.0024 & 0.0001 \\
\hline 22.03 .2001 & $S$ & 0.003 & -0.0025 & $0.0027^{* *}$ & 0.0022 & $-0.0043^{* *}$ & 0.0033 & $0.0046^{* *}$ \\
\hline 20.04.2001 & G & -0.006 & -0.0007 & -0.0005 & -0.0004 & 0.0005 & 0.001 & -0.0004 \\
\hline 14.06 .2001 & $S$ & 0.006 & -0.0018 & 0.0003 & -0.001 & -0.0004 & -0.0002 & -0.0003 \\
\hline 24.09.2001 & U & $-0.045^{* * *}$ & 0.0001 & 0.0011 & $0.0058^{* * *}$ & -0.0008 & 0.002 & 0.0033 \\
\hline 07.12 .2001 & $S$ & 0 & 0.0026 & -0.0005 & -0.0011 & -0.0018 & -0.0028 & 0.0011 \\
\hline 21.03.2002 & $S$ & $0.025^{* * *}$ & -0.0001 & 0.001 & -0.0001 & -0.0004 & 0.0004 & -0.0001 \\
\hline 26.04 .2002 & G & $0.019 * *$ & -0.0001 & -0.0003 & 0.0001 & -0.0017 & 0.0005 & -0.0002 \\
\hline 02.05.2002 & $U$ & $-0.016^{*}$ & -0.0001 & -0.0013 & -0.0008 & -0.0008 & 0.0001 & 0.0011 \\
\hline 14.06 .2002 & $S$ & -0.008 & $-0.0037^{*}$ & -0.0007 & $-0.0040 * *$ & 0.0019 & $-0.0047^{* *}$ & -0.00025 \\
\hline 26.07.2002 & U & $-0.178 * * *$ & 0.0018 & 0.002 & -0.0008 & $0.0045^{* *}$ & $0.0037^{*}$ & 0.0025 \\
\hline 19.09.2002 & $S$ & $0.029 * * *$ & 0.0007 & 0.0006 & -0.0021 & $-0.0037^{*}$ & 0.0023 & 0.0003 \\
\hline 13.12.2002 & $S$ & 0 & 0.0014 & -0.0002 & 0.0017 & -0.0031 & -0.0009 & 0.002 \\
\hline 06.03 .2003 & U & $-0.474^{* * *}$ & -0.0025 & $-0.0042^{* * *}$ & 0.0027 & -0.0004 & -0.0013 & -0.0013 \\
\hline 20.03.2003 & $S$ & 0 & 0.0002 & -0.0006 & 0.0019 & -0.0019 & -0.0002 & $-0.0044^{* *}$ \\
\hline 25.04 .2003 & G & 0 & 0 & 0.0008 & 0.0013 & -0.0016 & -0.0008 & -0.0011 \\
\hline 13.06 .2003 & $S$ & $0.08^{* * *}$ & -0.0031 & -0.0015 & $-0.0038^{* *}$ & -0.0013 & -0.0011 & 0.0004 \\
\hline 18.09 .2003 & $S$ & $-0.087^{* * *}$ & -0.0008 & 0.0005 & 0.0018 & 0.001 & 0.0005 & 0.0005 \\
\hline 12.12.2003 & $S$ & 0 & -0.0008 & 0.0005 & 0.0004 & 0.0009 & 0.0002 & -0.0004 \\
\hline 18.03 .2004 & $S$ & 0 & 0.0011 & -0.0009 & -0.0008 & 0 & -0.0001 & -0.0022 \\
\hline 30.04 .2004 & G & $-0.057^{* * *}$ & 0.0001 & -0.0002 & 0.0007 & 0.0003 & 0.0001 & -0.0003 \\
\hline 17.06 .2004 & $S$ & $-0.057^{* * *}$ & 0.0012 & 0.0001 & -0.0005 & -0.0003 & -0.0002 & -0.0001 \\
\hline 16.09.2004 & $S$ & -0.011 & -0.0007 & 0.0001 & 0.001 & 0.0016 & -0.0002 & 0 \\
\hline 16.12 .2004 & $S$ & $-0.067 * * *$ & 0.0002 & 0.0001 & -0.0001 & 0.0003 & 0.0003 & 0 \\
\hline 17.03.2005 & $S$ & -0.024 & 0 & 0.0004 & 0 & 0.001 & 0.0002 & 0 \\
\hline 29.04 .2005 & G & 0.013 & 0.0013 & 0.0001 & -0.0007 & -0.0028 & 0 & 0 \\
\hline 16.06 .2005 & $S$ & 0 & 0.0001 & 0.0002 & -0.0007 & 0 & -0.0002 & -0.0002 \\
\hline 15.09 .2005 & $S$ & $-0.026^{* * *}$ & -0.0002 & -0.0001 & -0.0002 & 0.0004 & 0.0006 & -0.0002 \\
\hline 15.12 .2005 & $S$ & -0.01 & -0.0011 & -0.0008 & -0.0019 & -0.0008 & -0.0018 & 0 \\
\hline \multicolumn{9}{|c|}{ All announcements } \\
\hline Anova F-stat & & $622 * * *$ & 0.34 & 0.77 & 0.52 & 0.61 & 0.1 & 0.05 \\
\hline Med. Chi-sq. & & $3.25^{* *}$ & 0.72 & 1.33 & 0.03 & 0.71 & 0.6 & $3.46^{*}$ \\
\hline Var. F-test & & $4229 * * *$ & $2.27^{* * *}$ & 1.31 & 1.21 & 1.4 & $1.68^{*}$ & $1.59 *$ \\
\hline \multicolumn{9}{|c|}{ Scheduled only } \\
\hline Anova F-stat & & $161^{* * *}$ & 0.47 & 0.05 & 0.52 & 0.6 & 0.1 & 0.15 \\
\hline Med. Chi-sq. & & $2.78^{*}$ & 1.69 & 0.92 & 0.04 & 0.71 & 0.25 & 0.59 \\
\hline Var. F-test & & $816^{* * *}$ & $2.28^{* * *}$ & $2.34 * * *$ & 1.21 & 1.41 & $1.68^{* *}$ & $1.59^{*}$ \\
\hline \multicolumn{9}{|c|}{ No unscheduled, no general meetings } \\
\hline Anova F-stat & & $188^{* * *}$ & 0.52 & 0.12 & 0.14 & 0.4 & 0.7 & 0.02 \\
\hline Med. Chi-sq. & & $2.9^{*}$ & 1.08 & 1.14 & 0.39 & 0.04 & 1.08 & 2.1 \\
\hline Var. F-test & & $1345 * * *$ & $1.94^{* *}$ & $1.98 * * *$ & 1.07 & 1.04 & 1.52 & 1.45 \\
\hline
\end{tabular}

* S means scheduled monetary policy decisions; U means unscheduled monetary policy decisions; $G$ stands for General Meeting. 
Table 4.2: Swiss equity market reactions to official speeches

Panel A: within trading hours

\begin{tabular}{|c|c|c|c|c|c|c|c|c|}
\hline date & $\begin{array}{l}30 \text { min } \\
\text { before }\end{array}$ & $\begin{array}{l}30 \text { min } \\
\text { after }\end{array}$ & $\begin{array}{c}\text { from } 30 \text { to } \\
60 \mathrm{~min}\end{array}$ & $\begin{array}{c}\text { from } 1 \mathrm{~h} \text { to } \\
2 \mathrm{~h}\end{array}$ & $\begin{array}{c}\text { within } 24 \\
\text { hours }\end{array}$ & day before & same day & day after \\
\hline 24.02 .2000 & 0.0007 & -0.0006 & 0 & 0.0008 & $-0.0155^{* *}$ & 0.0075 & -0.0031 & -0.006 \\
\hline 03.04 .2000 & -0.0011 & 0.0005 & $0.0048 * * *$ & 0.0012 & 0.0049 & 0.0053 & 0.008 & 0.0048 \\
\hline $25.08 .2000^{a}$ & 0.0012 & 0.0004 & $0.0029 *$ & 0.0008 & 0.0041 & -0.0019 & -0.0039 & 0.003 \\
\hline 07.09 .2001 & -0.0023 & 0.0030 * & 0.0010 & -0.0025 & 0.0034 & -0.0162 & $-0.0201^{*}$ & $-0.0199 *$ \\
\hline 14.09 .2001 & -0.0019 & 0.0027 & -0.0027 & $-0.0077^{* * *}$ & $-0.0518 * * *$ & 0.0092 & $-0.0443 * * *$ & 0 \\
\hline 17.09.2001 & $0.0029 *$ & $-0.0055^{* * *}$ & $0.0031^{*}$ & -0.0027 & $0.0496 * * *$ & $-0.0443 * * *$ & $0.0256^{* *}$ & -0.0119 \\
\hline 22.10 .2001 & -0.0004 & 0.0019 & $0.0062 * * *$ & 0.0026 & 0.0111 & -0.0038 & 0.0164 & 0.0157 \\
\hline 07.11 .2001 & 0.001 & 0.0001 & 0.0001 & -0.0023 & $0.0176^{* *}$ & 0.0018 & 0.0024 & $0.0223^{* *}$ \\
\hline 26.02 .2002 & -0.0018 & -0.0006 & 0.0003 & $-0.0056 * *$ & -0.0031 & 0.0072 & -0.0036 & 0.0166 \\
\hline $18.06 .2002^{a}$ & -0.0003 & $-0.0042^{* *}$ & -0.0004 & -0.0032 & -0.0035 & $0.0276^{* *}$ & -0.0132 & -0.0156 \\
\hline 23.07 .2002 & $0.0086^{* * *}$ & $-0.0041^{* *}$ & -0.0009 & -0.0004 & $-0.0427 * * *$ & $-0.0539 * * *$ & -0.0159 & -0.0084 \\
\hline 04.09 .2002 & 0.0016 & $-0.0094 * * *$ & -0.0002 & $0.0053^{* *}$ & $-0.0129 *$ & $-0.0333 * * *$ & 0.0071 & -0.0015 \\
\hline 23.09 .2002 & 0.0025 & 0.0018 & 0.0006 & -0.0009 & $-0.0441^{* * *}$ & 0.0012 & $-0.0356 * * *$ & -0.001 \\
\hline 30.11 .2002 & -0.0012 & $0.0039 * *$ & $0.0046^{* * *}$ & 0.0025 & -0.0012 & -0.0052 & 0.0067 & -0.0268 ** \\
\hline $05.06 .2003^{a}$ & $-0.0071^{* * *}$ & -0.0008 & 0.0014 & -0.0017 & 0.0046 & 0.0071 & -0.0079 & 0.0165 \\
\hline 26.06 .2003 & 0.0003 & $0.0037 * *$ & -0.0011 & -0.0003 & -0.0025 & 0.0006 & 0.0031 & 0.0009 \\
\hline 19.08.2003 & 0.0018 & 0.0005 & 0 & $-0.0043^{*}$ & -0.0029 & 0.0055 & 0.004 & -0.0056 \\
\hline 30.08 .2003 & $-0.0076 * * *$ & 0.0026 & 0.0005 & $0.0054^{* *}$ & 0.0023 & -0.0131 & 0.0174 & -0.0054 \\
\hline 19.11.2004 & 0.0006 & 0.0008 & -0.0006 & -0.0001 & $-0.0143^{*}$ & -0.0009 & -0.0109 & -0.0076 \\
\hline 07.12 .2005 & -0.0003 & -0.001 & 0.0007 & $0.0046^{*}$ & 0.0014 & 0.0029 & -0.0026 & -0.0035 \\
\hline$\%$ signif. & $6 \%$ & $10 \%$ & $7 \%$ & $9 \%$ & $12 \%$ & $6 \%$ & $6 \%$ & $4 \%$ \\
\hline Anova F-stat & 0.18 & 0.41 & 0.44 & 0.91 & 1.23 & 1.82 & 0.08 & 0.03 \\
\hline Med. Chi-sq. & 0.01 & 0.72 & 0.19 & $6.49 * *$ & 0.01 & 0.02 & 0.13 & 0.13 \\
\hline Var. F-test & $1.96 * * *$ & $2.21 * * *$ & $3.42 * *$ & $4.07 * * *$ & 1.2 & 1.04 & 1.09 & 1.23 \\
\hline
\end{tabular}

\section{Panel B: off market}

\begin{tabular}{lccc} 
date & day before & same day & day after \\
\hline 30.10 .2001 & -0.0184 & $-0.0211^{*}$ & 0.0119 \\
18.02 .2002 & -0.0006 & -0.0055 & $-0.022^{*}$ \\
12.06 .2002 & 0.0097 & $-0.0289^{* *}$ & -0.0140 \\
21.06 .2002 & $-0.0306^{* * *}$ & 0.0018 & $-0.0324^{* * *}$ \\
25.06 .2002 & $-0.0324^{* * *}$ & $0.0306^{* * *}$ & $-0.0263^{* *}$ \\
10.09 .2002 & -0.0134 & 0.0168 & $0.0226^{* *}$ \\
26.09 .2002 & 0.0166 & $0.0492^{* * *}$ & 0.0025 \\
30.09 .2002 & 0.0025 & $-0.0235^{* *}$ & -0.0133 \\
22.10 .2002 & -0.0095 & -0.0072 & $-0.0219^{*}$ \\
21.01 .2003 & -0.0148 & -0.0053 & $-0.0265^{* *}$ \\
24.01 .2003 & 0.0001 & -0.0106 & $-0.0356^{* *}$ \\
17.03 .2003 & $0.053^{* * *}$ & $0.0262^{* *}$ & 0.0089 \\
31.03 .2003 & 0.0036 & $-0.0274^{* *}$ & 0.0111 \\
22.05 .2003 & -0.0134 & $0.0245^{* *}$ & 0.0017 \\
16.06 .2003 & -0.0166 & $0.0198^{*}$ & 0.0095 \\
02.10 .2003 & 0.0028 & 0.0043 & $0.0231^{*}$ \\
& & & \\
\% signif. & $4 \%$ & $12 \%$ & $10 \%$ \\
Anova F-stat & 0.1 & 0.7 & 1.24 \\
Med. Chi-sq. & 1.23 & 1.61 & 0.01 \\
Var. F-test & 1.19 & 1.05 & 1.17 \\
\hline & & &
\end{tabular}

${ }^{a}$ Overlapping events: this speech was preceded by an interview. 
Table 4.3: Swiss equity market reactions to interviews

Panel A: within trading hours

\begin{tabular}{|c|c|c|c|c|c|c|c|c|}
\hline date & $\begin{array}{l}30 \text { min } \\
\text { before }\end{array}$ & $\begin{array}{c}30 \text { min } \\
\text { after }\end{array}$ & $\begin{array}{c}\text { from } 30 \text { to } \\
60 \mathrm{~min}\end{array}$ & $\begin{array}{c}\text { from } 1 \mathrm{~h} \text { to } \\
2 \mathrm{~h}\end{array}$ & $\begin{array}{c}\text { within } 24 \\
\text { hours }\end{array}$ & day before & same day & day after \\
\hline 11.05 .2000 & 0.0016 & $0.0029^{*}$ & 0.0026 & 0.0029 & $0.0174 * *$ & -0.0047 & 0.0162 & 0.0046 \\
\hline 10.05 .2001 & $0.0031^{*}$ & 0.0004 & 0.0003 & 0.0012 & 0.0019 & -0.0073 & 0 & 0.0138 \\
\hline 21.09.2001 & $-0.0066 * * *$ & $-0.0084 * * *$ & $0.0084^{* * *}$ & $-0.0108 * * *$ & 0.0049 & $-0.0454 * * *$ & $-0.0518 * * *$ & $0.0569 * * *$ \\
\hline 03.01 .2002 & 0.0027 & $-0.0048 * * *$ & 0.0003 & -0.0003 & -0.0009 & -0.0072 & 0.0018 & 0.003 \\
\hline 18.06 .2002 & -0.0012 & -0.0015 & $-0.007 * * *$ & -0.0024 & -0.0043 & $0.0276^{* *}$ & -0.0132 & -0.0156 \\
\hline $23.07 .2002^{a}$ & $-0.0036^{* *}$ & 0.0015 & -0.0011 & $-0.0061^{* *}$ & $-0.069 * * *$ & -0.0539 & $-0.0159 * * *$ & -0.0084 \\
\hline 25.07 .2002 & $-0.0076^{* * *}$ & $-0.0035^{* *}$ & 0.0029 & $0.0149 * * *$ & $0.0471^{* * *}$ & -0.0084 & $0.0579 * * *$ & $0.0218^{*}$ \\
\hline 02.09 .2002 & -0.0026 & $-0.0055^{* * *}$ & 0.0006 & 0.0028 & -0.0116 & 0.0181 & $-0.0248 * *$ & $-0.0333 * * *$ \\
\hline 12.09.2002 & 0.0018 & -0.0025 & -0.0022 & 0.0015 & $-0.0192^{* *}$ & $0.0226^{* *}$ & $-0.0308 * * *$ & $-0.0233^{* *}$ \\
\hline 11.11 .2002 & 0.0019 & -0.0007 & -0.0008 & $0.0047^{*}$ & 0.0068 & -0.0104 & -0.0108 & 0.0123 \\
\hline 05.12 .2002 & 0.0012 & $-0.0031^{*}$ & 0.0002 & $-0.0051^{* *}$ & $-0.028 * * *$ & 0.0002 & -0.0113 & -0.0038 \\
\hline 20.12.2002 & 0 & 0.0003 & -0.0024 & $0.0053 * *$ & 0.0027 & -0.0046 & -0.0010 & -0.0086 \\
\hline 27.01 .2003 & -0.0016 & -0.0007 & $-0.0041^{\star}$ & $0.0101 * * *$ & $-0.023 * * *$ & -0.0106 & $-0.0356 * * *$ & 0 \\
\hline 28.01 .2003 & 0.0009 & $-0.0059 * * *$ & $-0.0084^{* * *}$ & -0.0016 & $-0.024 * * *$ & $-0.0356 * * *$ & -0.0038 & 0.0047 \\
\hline 24.02 .2003 & -0.0021 & 0.0012 & -0.0019 & -0.0013 & $-0.0136^{*}$ & 0.003 & -0.0109 & $-0.0201^{*}$ \\
\hline 02.04 .2003 & $0.0095 * * *$ & $0.0061^{* * *}$ & -0.0002 & -0.0014 & $0.0147^{*}$ & 0.0111 & $0.0308 * * *$ & 0.0121 \\
\hline 07.04 .2003 & 0.0003 & $0.0031 *$ & 0.004 & 0.004 & -0.009 & 0.0147 & 0.0232 ** & -0.0056 \\
\hline 05.06 .2003 & -0.0021 & 0.0018 & $-0.0055^{* *}$ & -0.0026 & -0.0009 & 0.0071 & -0.0079 & 0.0165 \\
\hline 18.06 .2003 & 0.0011 & $0.0038^{* *}$ & $0.0042^{*}$ & 0.0024 & 0.0027 & 0.0095 & 0.0077 & -0.0141 \\
\hline $15.08 .2003^{b}$ & 0.0007 & $0.0048 * * *$ & -0.0019 & -0.0017 & 0.0087 & 0.008 & 0.0119 & 0.0055 \\
\hline 01.10 .2003 & $-0.0038 * *$ & 0.002 & 0.0022 & $-0.0056 * *$ & 0.0041 & -0.0112 & 0.0028 & 0.0043 \\
\hline$\%$ signif. & $13 \%$ & $20 \%$ & $11 \%$ & $15 \%$ & $17 \%$ & $7 \%$ & $15 \%$ & $9 \%$ \\
\hline Anova F-stat & 0.05 & 0.02 & 0.31 & 0.11 & 0.80 & 0 & 0.10 & 0.03 \\
\hline Med. Chi-sq. & $3.65^{*}$ & 1.86 & 1.19 & 0.00 & 1.43 & 0.31 & 0.68 & 0.68 \\
\hline Var. F-test & $1.53^{* *}$ & $1.47^{* *}$ & $1.36^{*}$ & $1.41^{*}$ & 1.59 ** & $1.63^{* *}$ & $1.92^{* * *}$ & 1.13 \\
\hline
\end{tabular}

\section{Panel B: off market}

\begin{tabular}{lccc} 
date & day before & same day & day after \\
\hline 06.10 .2000 & 0.0021 & -0.0051 & $-0.0197^{*}$ \\
19.02 .2002 & -0.0055 & $-0.022^{*}$ & -0.0056 \\
03.07 .2002 & $-0.0204^{*}$ & $-0.0247^{* *}$ & $0.0224^{*}$ \\
06.11 .2002 & 0.0022 & -0.0045 & $-0.0206^{*}$ \\
04.03 .2003 & 0.0089 & $-0.0323^{* *}$ & $-0.0192^{*}$ \\
12.03 .2003 & -0.0039 & -0.0113 & $0.029^{*}$ \\
18.03 .2003 & $0.0262^{* *}$ & 0.0089 & $0.0224^{*}$ \\
14.04 .2003 & 0.0161 & 0.0091 & $0.0229^{*}$ \\
16.06 .2003 & -0.0166 & $0.0198^{*}$ & 0.0095 \\
19.10 .2005 & 0.0077 & $-0.0184^{*}$ & 0.009 \\
& & & $6 \%$ \\
\% signif. & $2 \%$ & $4 \%$ & 0.01 \\
Anova F-stat & 0.29 & 0.4 & 0.59 \\
Med. Chi-sq. & 0.01 & $2.65^{*}$ & 1.2 \\
Var. F-test & $2.33^{* * *}$ & $1.47^{* * *}$ & \\
\hline
\end{tabular}

\footnotetext{
${ }^{a}$ Overlapping events: this interview was preceded by a speech.

${ }^{\mathrm{b}}$ Overlapping events: this interview was preceded by another interview.
} 
Table 5.1: Swiss bond market reactions to monetary policy announcements

\begin{tabular}{|c|c|c|c|c|c|c|c|c|}
\hline Date & $S / U^{*}$ & Surprise & $\begin{array}{l}15 \mathrm{~min} \\
\text { before }\end{array}$ & 5 min after & $\begin{array}{c}\text { From } 5 \text { to } 15 \\
\min \end{array}$ & $\begin{array}{c}\text { From } 15 \text { to } \\
30 \mathrm{~min}\end{array}$ & $\begin{array}{c}\text { From } 30 \text { to } \\
45 \mathrm{~min}\end{array}$ & $\begin{array}{c}\text { From } 45 \text { to } \\
60 \mathrm{~min}\end{array}$ \\
\hline 20.01 .2000 & $U$ & $0.018^{*}$ & 0 & 0 & -0.0001 & 0.0001 & $0.0006^{* *}$ & 0 \\
\hline 03.02 .2000 & U & $0.067^{* * *}$ & 0.0002 & 0.0001 & $0.0005^{* *}$ & -0.0003 & -0.0003 & -0.0001 \\
\hline 23.03 .2000 & $S$ & $0.054 * * *$ & 0 & 0 & $-0.0004 * *$ & -0.0001 & -0.0001 & 0 \\
\hline 28.04 .2000 & G & 0.009 & 0 & $-0.0004^{* * *}$ & $0.0004^{\star}$ & 0 & 0 & 0.0001 \\
\hline 15.06 .2000 & $S$ & 0.003 & 0.0002 & 0 & 0.0002 & -0.0003 & -0.0003 & -0.0003 \\
\hline 14.09 .2000 & $S$ & -0.003 & 0 & 0 & 0 & 0.0002 & 0.0001 & 0 \\
\hline 08.12 .2000 & $S$ & 0 & -0.0002 & 0.0001 & 0.0001 & 0.0003 & 0 & 0 \\
\hline 22.03.2001 & $S$ & 0.003 & 0 & 0 & 0.0002 & -0.0001 & 0 & -0.0001 \\
\hline 20.04.2001 & G & -0.006 & -0.0002 & 0.0001 & 0.0001 & 0.0001 & 0.0003 & 0 \\
\hline 14.06.2001 & $S$ & 0.006 & 0.0002 & $-0.0002^{*}$ & $-0.0004^{*}$ & -0.0004 & $-0.0006^{* *}$ & $-0.0005^{*}$ \\
\hline 24.09 .2001 & U & $-0.045^{* * *}$ & -0.0001 & 0.0001 & 0.0001 & 0.0001 & 0 & 0.0001 \\
\hline 07.12 .2001 & $S$ & 0 & 0 & 0.0001 & 0.0001 & 0 & -0.0003 & 0.0002 \\
\hline 21.03.2002 & $S$ & $0.025 * * *$ & 0 & 0.0002 & -0.0002 & 0 & -0.0001 & 0 \\
\hline 26.04.2002 & G & $0.019 * *$ & -0.0002 & 0 & -0.0001 & -0.0002 & 0.0002 & 0 \\
\hline 02.05 .2002 & U & $-0.016^{\star}$ & 0 & 0 & 0.0003 & $0.0005^{* *}$ & 0.0001 & 0.0002 \\
\hline 14.06.2002 & $S$ & -0.008 & 0.0002 & -0.0003 & 0 & 0 & 0 & 0.0001 \\
\hline 26.07 .2002 & U & $-0.178 * * *$ & -0.0004 & 0 & 0.0001 & 0.0001 & 0.0004 & 0.0001 \\
\hline 19.09.2002 & $S$ & $0.029 * * *$ & 0 & 0 & 0.0001 & 0.0001 & 0.0004 & 0 \\
\hline 13.12 .2002 & $S$ & 0 & 0.0002 & -0.0001 & 0 & 0.0001 & 0.0001 & 0 \\
\hline 18.03 .2004 & $S$ & 0 & -0.0001 & -0.0001 & 0 & 0.0001 & -0.0001 & -0.0002 \\
\hline 30.04 .2004 & G & $-0.057 * * *$ & -0.0001 & 0.0001 & $0.0009 * * *$ & $0.0006^{* *}$ & 0.0002 & $0.0008 * * *$ \\
\hline 17.06 .2004 & $S$ & $-0.057^{* * *}$ & 0.0004 & -0.0001 & $-0.0008^{* * *}$ & $-0.0011^{* * *}$ & 0.0004 & 0.0001 \\
\hline 16.09 .2004 & $S$ & -0.011 & -0.0001 & 0.0001 & 0.0002 & 0.0003 & 0.0001 & 0.0001 \\
\hline 16.12 .2004 & $S$ & $-0.067 * * *$ & 0.0001 & 0.0001 & $0.0005^{* *}$ & 0.0001 & -0.0001 & 0.0001 \\
\hline 17.03 .2005 & $S$ & -0.024 & 0.0001 & 0.0001 & $0.0007 * * *$ & -0.0002 & 0.0003 & -0.0001 \\
\hline 29.04.2005 & G & 0.013 & -0.0003 & 0.0001 & $-0.0007^{* * *}$ & 0.0003 & 0.0002 & 0.0001 \\
\hline 16.06 .2005 & $S$ & 0 & 0.0001 & -0.0001 & -0.0003 & $-0.0008^{* * *}$ & $-0.0007 * * *$ & 0.0001 \\
\hline 15.09 .2005 & $S$ & $-0.026^{* * *}$ & 0 & $-0.0019 * * *$ & $0.0009 * * *$ & $0.0014^{* * *}$ & -0.0001 & $-0.0019 * * *$ \\
\hline 15.12 .2005 & $S$ & -0.01 & 0.0001 & $-0.0014^{* * *}$ & $0.0013^{* * *}$ & $0.0032^{* * *}$ & 0.0001 & -0.0004 \\
\hline \multicolumn{9}{|c|}{ All announcements } \\
\hline Anova F-stat & & $572 * * *$ & 0.13 & $42.55^{* * *}$ & $20.71^{\star * *}$ & $15.01 * * *$ & 0.38 & 2.11 \\
\hline Med. Chi-sq. & & $3.15^{* *}$ & 0.8 & $7.03 * * *$ & $15.05^{* * *}$ & $7.12 * * *$ & $3.51^{*}$ & 1.16 \\
\hline Var. F-test & & $3829 * * *$ & $1.67^{*}$ & $21.05^{* * *}$ & $10.01^{* * *}$ & $16.2^{* * *}$ & $2.54^{* * *}$ & $5.33^{* * *}$ \\
\hline \multicolumn{9}{|c|}{ Scheduled only } \\
\hline Anova F-stat & & $141^{* * *}$ & 0.70 & $57.22 * * *$ & $14.23^{* * *}$ & $15.51 * * *$ & 0.39 & $2.97^{*}$ \\
\hline Med. Chi-sq. & & $2.77^{*}$ & 0.33 & $5.56^{* *}$ & $9.77^{* * *}$ & $7.12 * * *$ & $3.51^{*}$ & 1.16 \\
\hline Var. F-test & & $601 * * *$ & 1.27 & $24.89 * * *$ & $11.72^{* * *}$ & $16.2^{* * *}$ & $2.54 * * *$ & $5.33^{* * *}$ \\
\hline \multicolumn{9}{|c|}{ No unscheduled, no general meetings } \\
\hline Anova F-stat & & $158^{* * *}$ & 1.84 & $68.02 * * *$ & $22.64 * * *$ & $11.13^{* * *}$ & $11.1^{* * *}$ & $9.59 * * *$ \\
\hline Med. Chi-sq. & & $2.6^{*}$ & 2.05 & 2.06 & $12.69 * * *$ & $6.95^{* * *}$ & 2.02 & 0.33 \\
\hline Var. F-test & & $854^{* * *}$ & 1.71 & $30.1^{* * *}$ & $10.86^{* * *}$ & $11.24^{* * *}$ & $24.04^{* * *}$ & $6.5^{* * *}$ \\
\hline
\end{tabular}

* $\mathrm{S}$ means scheduled monetary policy decisions; U means unscheduled monetary policy decisions; $\mathrm{G}$ stands for General Meeting. 
Table 5.2: Swiss bond market reactions to official speeches

Panel A: within trading hours

\begin{tabular}{|c|c|c|c|c|c|c|c|c|}
\hline date & $\begin{array}{l}30 \text { min } \\
\text { before }\end{array}$ & 30 min after & $\begin{array}{c}\text { from } 30 \text { to } \\
60 \mathrm{~min}\end{array}$ & $\begin{array}{c}\text { from } 1 \mathrm{~h} \text { to } \\
2 \mathrm{~h}\end{array}$ & $\begin{array}{c}\text { since } 24 \\
\text { hours }\end{array}$ & day before & same day & day after \\
\hline 03.04 .2000 & 0 & $0.0004^{* *}$ & 0.0004 & 0.0001 & $0.0025^{* * *}$ & -0.0016 & -0.0006 & 0.002 \\
\hline 12.07 .2000 & 0 & -0.0002 & -0.0001 & -0.0001 & $-0.0019 * *$ & 0.0016 & 0 & -0.001 \\
\hline 25.08 .2000 & 0 & $0.0008^{* * *}$ & 0.0002 & 0.0002 & 0.0013 & 0.0011 & 0.0012 & 0.0007 \\
\hline 16.01 .2001 & 0 & 0 & 0 & -0.0001 & $-0.0027^{* *}$ & -0.0006 & -0.0001 & -0.0016 \\
\hline 09.05 .2001 & $0.0005^{* *}$ & -0.0001 & 0.0002 & 0.0002 & 0.0007 & 0.0003 & 0.0005 & 0.0006 \\
\hline 07.09 .2001 & $-0.0005^{* *}$ & 0.0001 & 0 & 0.0001 & 0.0006 & 0.0003 & 0.0016 & 0.0006 \\
\hline 14.09 .2001 & 0.0002 & 0.0002 & 0.0001 & 0.0001 & $0.0023^{* * *}$ & -0.0004 & 0.0013 & 0 \\
\hline 17.09 .2001 & $0.0004^{*}$ & 0 & 0 & 0.0001 & 0.0002 & 0.0013 & 0.0007 & 0.0008 \\
\hline 26.02.2002 & 0.0001 & 0 & -0.0002 & $0.0006^{*}$ & -0.0002 & -0.0005 & -0.0006 & -0.001 \\
\hline 04.09 .2002 & $-0.0006^{* * *}$ & 0.0001 & $0.0005^{*}$ & -0.0001 & $0.0033^{* * *}$ & 0.0021 & 0.0015 & $0.0028^{* *}$ \\
\hline 23.09.2002 & 0.0001 & 0 & 0.0001 & -0.0002 & $0.0016^{*}$ & -0.0003 & 0.0006 & 0.0008 \\
\hline 04.11 .2002 & $-0.0005^{* *}$ & $-0.0004^{* *}$ & 0.0001 & 0.0001 & -0.0012 & 0.0019 & -0.0009 & -0.0002 \\
\hline 11.02 .2003 & $-0.0009^{* * *}$ & 0 & -0.0004 & $0.0005^{*}$ & 0.0011 & 0.0001 & -0.0002 & 0.0014 \\
\hline 21.05 .2003 & $-0.0009 * * *$ & 0 & -0.0004 & $0.0005^{*}$ & 0.0011 & -0.0008 & 0.0005 & -0.0005 \\
\hline $05.06 .2003^{\mathrm{a}}$ & $-0.0009 * * *$ & -0.0003 & -0.0001 & 0.0004 & 0.0011 & 0.0015 & $0.0025^{*}$ & -0.0002 \\
\hline 26.06 .2003 & 0.0001 & $-0.0004^{* *}$ & 0.0001 & 0.0004 & 0.0011 & 0.0015 & $-0.003 * *$ & 0.0011 \\
\hline 19.08 .2003 & 0 & $-0.0004^{* *}$ & 0.0001 & 0.0004 & 0.0011 & 0.0005 & -0.0011 & 0.0011 \\
\hline 30.08 .2003 & 0 & $-0.0004^{* *}$ & $0.0005^{*}$ & 0 & 0.0011 & -0.0002 & -0.0008 & $-0.0049 * * *$ \\
\hline 08.10 .2003 & 0 & $-0.0004^{* *}$ & $0.0005^{*}$ & $-0.0005^{*}$ & 0.001 & 0.001 & -0.0004 & 0.0001 \\
\hline 27.10 .2003 & 0 & $-0.0004^{*}$ & 0.0004 & -0.0001 & 0.001 & 0 & -0.0018 & -0.0011 \\
\hline 05.12 .2003 & $-0.0006^{* * *}$ & -0.0002 & 0.0001 & 0 & $0.0022 * *$ & 0.0006 & $0.0024^{*}$ & $0.0024^{*}$ \\
\hline $29.01 .2004^{a}$ & $-0.0006^{* * *}$ & 0 & 0 & -0.0001 & $-0.0024^{* * *}$ & 0.0008 & $-0.0035^{* * *}$ & 0.0005 \\
\hline 08.03 .2004 & -0.0001 & 0.0002 & -0.0001 & $0.001 * * *$ & $0.0022^{* *}$ & $0.0033^{* *}$ & $0.0028^{* *}$ & 0 \\
\hline 23.04.2004 & 0.0001 & 0 & 0 & 0 & $-0.0042 * * *$ & -0.0002 & -0.0009 & -0.0016 \\
\hline 07.05 .2004 & 0.0003 & $0.0005^{* *}$ & 0.0003 & 0 & -0.001 & $-0.0025^{*}$ & $-0.0031^{* *}$ & -0.0013 \\
\hline 04.06 .2004 & $-0.0007 * * *$ & 0.0003 & 0 & -0.0001 & -0.0013 & -0.0015 & -0.0015 & -0.0004 \\
\hline 18.11 .2004 & -0.0001 & -0.0003 & $-0.0007^{* *}$ & 0.0003 & -0.0003 & -0.0014 & -0.0018 & 0 \\
\hline 23.11 .2004 & -0.0001 & 0.0003 & -0.0001 & -0.0001 & $0.0026^{* * *}$ & 0.0017 & 0.001 & 0.0012 \\
\hline 06.12 .2004 & 0 & 0.0001 & 0.0001 & 0.0001 & $0.0023^{* *}$ & 0.0005 & 0.0021 & 0.001 \\
\hline 11.01 .2005 & $-0.001 * * *$ & $0.001^{* * *}$ & 0.0002 & -0.0001 & 0.0007 & 0.0005 & 0 & -0.0004 \\
\hline 02.02 .2005 & 0.0001 & 0.0001 & 0.0005 & 0.0001 & $0.0019 * *$ & 0.0018 & 0.0004 & -0.0003 \\
\hline 04.02 .2005 & $0.0009 * * *$ & -0.0001 & 0.0003 & $0.0019 * * *$ & $0.0042 * * *$ & -0.0003 & $0.0024^{*}$ & 0.0008 \\
\hline 04.03 .2005 & 0.0003 & $0.0005^{* *}$ & 0 & $0.0007^{* *}$ & $0.006^{* * *}$ & $0.0023 *$ & 0.002 & 0 \\
\hline 07.03 .2005 & 0.0002 & 0.0002 & 0 & 0 & $0.0034^{* * *}$ & 0.002 & 0.0008 & 0.0007 \\
\hline 21.04.2005 & 0 & -0.0002 & 0.0005 & -0.0001 & $0.0039 * * *$ & -0.0009 & -0.0002 & 0.0001 \\
\hline 27.05 .2005 & 0.0001 & $0.0009 * * *$ & -0.0003 & 0 & 0.0013 & -0.0008 & 0.0001 & 0.0002 \\
\hline 14.06.2005 & -0.0001 & -0.0001 & 0.0001 & $0.0007^{* *}$ & $-0.0027^{* * *}$ & -0.0007 & -0.0006 & $-0.0034^{* *}$ \\
\hline 29.08.2005 & 0.0001 & $0.0004^{* *}$ & 0 & -0.0001 & 0.0008 & 0.0003 & 0.0002 & -0.0002 \\
\hline 02.11 .2005 & $-0.0023^{* * *}$ & $-0.0008^{* * *}$ & 0.0001 & $-0.0025^{* * *}$ & $0.0023^{* *}$ & -0.0007 & $-0.0029 * *$ & -0.0013 \\
\hline 29.11.2005 & 0.0001 & $0.0012^{* * *}$ & 0.0004 & $-0.0006^{* *}$ & $0.0036 * * *$ & -0.0005 & 0.0011 & 0.0006 \\
\hline 07.12 .2005 & $0.0012^{* * *}$ & -0.0003 & 0.0003 & $0.0006^{* *}$ & 0.0015 & $0.0031^{* *}$ & -0.0008 & 0.0017 \\
\hline$\%$ signif. & $23 \%$ & $23 \%$ & $6 \%$ & $17 \%$ & $30 \%$ & $6 \%$ & $12 \%$ & $6 \%$ \\
\hline Anova F-stat & $9.98^{* * *}$ & $3.13^{*}$ & $3.37^{*}$ & 1.49 & $22.15^{* * *}$ & 1.1 & 0.38 & 0.05 \\
\hline Med. Chi-sq. & 0.4 & 0.28 & $4.22^{* *}$ & 0.36 & $11.03^{* * *}$ & 0.18 & $2.85^{*}$ & 0.18 \\
\hline Var. F-test & $4.44^{* * *}$ & $2.33^{* * *}$ & 1.3 & $2.06^{* * *}$ & $2.46^{* * *}$ & 1.03 & 1.01 & 1.06 \\
\hline
\end{tabular}




\section{Panel B: off market}

\begin{tabular}{lccc} 
date & day before & same day & day after \\
\hline 07.04 .2000 & -0.0006 & 0.0007 & $0.0031^{* *}$ \\
30.09 .2002 & 0.0005 & $0.0026^{* *}$ & -0.0004 \\
05.12 .2002 & 0.0001 & 0.0009 & $0.0026^{*}$ \\
17.03 .2003 & $-0.0032^{* *}$ & $-0.0032^{* *}$ & $-0.0069^{* * *}$ \\
26.03 .2003 & -0.0011 & -0.0020 & $0.0035^{* * *}$ \\
31.03 .2003 & 0.0009 & $0.0041^{* * *}$ & 0.0008 \\
06.05 .2003 & 0.0003 & 0.0009 & $0.0037^{* * *}$ \\
12.06 .2003 & 0.0009 & $-0.0022^{*}$ & -0.0011 \\
$16.06 .2003^{b}$ & -0.0011 & 0.0004 & $-0.0031^{* *}$ \\
01.09 .2003 & -0.0002 & -0.0008 & $-0.0049^{* * *}$ \\
02.10 .2003 & 0.0006 & $-0.0025^{*}$ & $-0.0024^{*}$ \\
09.03 .2005 & 0.0007 & 0 & $-0.0038^{* * *}$ \\
09.11 .2005 & 0.0005 & 0 & $-0.0027^{* *}$ \\
& & & \\
\% signif. & $1 \%$ & $6 \%$ & $13 \%$ \\
Anova F-stat & 0.48 & $2.75^{*}$ & $3.41^{*}$ \\
Med. Chi-sq. & 0.41 & 2.18 & 1.91 \\
Var. F-test & $1.82^{* * *}$ & 1.05 & $1.65^{* * *}$ \\
\hline
\end{tabular}

a Overlapping events: this speech was preceded by an interview.

${ }^{\mathrm{b}}$ Overlapping events: this speech was preceded by another speech. 
Table 5.3: Swiss bond market reaction to interviews

Panel A: within trading hours

\begin{tabular}{|c|c|c|c|c|c|c|c|c|}
\hline date & $\begin{array}{l}30 \text { min } \\
\text { before }\end{array}$ & $\begin{array}{l}30 \text { min } \\
\text { after }\end{array}$ & $\begin{array}{c}\text { from } 30 \text { to } \\
60 \mathrm{~min}\end{array}$ & $\begin{array}{c}\text { from } 1 \mathrm{~h} \text { to } \\
2 \mathrm{~h}\end{array}$ & $\begin{array}{c}\text { within } 24 \\
\text { hours }\end{array}$ & day before & same day & day after \\
\hline 12.01 .2000 & 0.0002 & 0.0003 & 0.0003 & 0 & $0.0023 * *$ & -0.001 & -0.0001 & 0.0004 \\
\hline 03.08 .2000 & -0.0003 & 0 & 0 & $-0.0005^{*}$ & $-0.0016^{*}$ & 0.0005 & -0.0003 & -0.0001 \\
\hline $25.08 .2000^{a}$ & 0 & $0.0008 * * *$ & 0.0002 & 0.0002 & 0.0013 & 0.0011 & 0.0012 & 0.0007 \\
\hline 31.08 .2000 & 0.0001 & $0.0003^{*}$ & -0.0001 & $-0.0015^{* * *}$ & $-0.0019 * *$ & -0.0002 & -0.0003 & 0.0014 \\
\hline 30.04 .2001 & -0.0002 & $-0.0004^{* *}$ & -0.0004 & $-0.0005^{\star}$ & -0.0015 & -0.0002 & -0.0016 & 0 \\
\hline 10.05 .2001 & 0.0001 & -0.0002 & -0.0003 & $-0.0009 * * *$ & -0.0015 & 0.0005 & 0 & 0.0006 \\
\hline 03.01 .2002 & 0.0001 & $0.0004^{*}$ & $0.001 * * *$ & 0.0003 & $0.0036 * * *$ & 0 & 0.0016 & 0.0008 \\
\hline 27.03 .2002 & 0.0001 & 0.0002 & 0 & 0.0001 & $0.0019 * *$ & 0.0008 & $0.0022^{*}$ & 0.0017 \\
\hline 14.05 .2002 & -0.0001 & 0 & 0 & $0.0005^{*}$ & 0.0012 & 0.0004 & -0.0017 & -0.0001 \\
\hline $23.07 .2002^{b}$ & 0.0002 & 0.0002 & 0.0001 & -0.0001 & $0.002 * *$ & 0.0022 & 0.0004 & $0.0034^{*}$ \\
\hline 25.07 .2002 & -0.0003 & 0.0001 & 0.0004 & $-0.0005^{*}$ & 0.0001 & $0.0034 * *$ & -0.0014 & 0.0003 \\
\hline 02.09 .2002 & 0.0001 & $0.0004^{*}$ & -0.0001 & 0.0003 & $0.002 * *$ & 0.0005 & 0.0011 & 0.0021 \\
\hline 12.09 .2002 & $0.0008 * * *$ & $0.0011^{* * *}$ & 0.0001 & -0.0003 & $0.0026 * * *$ & -0.0005 & $0.0024^{*}$ & $0.0032 * *$ \\
\hline 05.12 .2002 & $-0.0009 * * *$ & 0 & -0.0003 & 0.0003 & 0.0009 & 0.0001 & 0.0009 & $0.0026^{*}$ \\
\hline 27.01 .2003 & $-0.0009 * * *$ & 0 & -0.0004 & 0.0004 & 0.0009 & 0.0017 & 0.0005 & 0 \\
\hline 28.01 .2003 & $-0.0009 * * *$ & 0 & -0.0004 & 0.0004 & 0.0011 & 0.0005 & -0.0007 & 0.0005 \\
\hline 24.02 .2003 & $-0.0009 * * *$ & 0 & -0.0004 & 0.0004 & 0.0011 & -0.0006 & 0.0009 & 0.0003 \\
\hline 02.04 .2003 & 0.0001 & 0 & -0.0004 & $0.0005^{*}$ & 0.0011 & 0.0008 & $-0.0024^{*}$ & $-0.0037^{* * *}$ \\
\hline 07.04 .2003 & 0 & 0 & -0.0004 & $0.0005^{*}$ & 0.0011 & -0.0005 & $-0.0044 * * *$ & 0.0007 \\
\hline 18.06 .2003 & 0 & $-0.0004^{* *}$ & 0.0001 & 0.0004 & 0.0011 & $-0.0031^{* *}$ & $-0.0054 * * *$ & $-0.0039 * * *$ \\
\hline $15.08 .2003^{a}$ & 0 & $-0.0004^{* *}$ & 0.0001 & 0.0004 & 0.0011 & $-0.0031^{* *}$ & 0.0007 & 0.0005 \\
\hline 21.08.2003 & 0 & $-0.0004^{* *}$ & 0.0005 & 0 & 0.0011 & 0.0011 & -0.0016 & -0.0006 \\
\hline 01.10 .2003 & 0 & $-0.0004^{* *}$ & 0.0005 & -0.0005 & 0.001 & $0.0033^{* *}$ & 0.0006 & $-0.0025^{*}$ \\
\hline 22.10 .2003 & 0 & $-0.0004^{*}$ & 0.0004 & -0.0001 & 0.001 & 0.0009 & 0.0014 & 0.0006 \\
\hline 29.01.2004 & 0.0001 & $-0.0009 * * *$ & -0.0001 & $-0.0006 * *$ & $-0.0043^{* * *}$ & 0.0008 & $-0.0035^{* * *}$ & 0.0005 \\
\hline $23.11 .2004^{b}$ & 0.0001 & 0.0001 & $0.0005^{*}$ & $0.0007 * *$ & $0.0029 * * *$ & 0.0017 & 0.001 & 0.0012 \\
\hline 17.01 .2005 & -0.0002 & 0.0001 & 0.0003 & $0.0005^{*}$ & $0.0018 * *$ & -0.0008 & 0.0013 & 0 \\
\hline 28.01 .2005 & -0.0001 & $0.0017 * * *$ & -0.0003 & 0 & $0.0025 * * *$ & -0.0005 & 0.001 & 0.0007 \\
\hline 08.04 .2005 & 0 & 0 & 0.0001 & 0.0001 & $0.0019 * *$ & 0.0017 & -0.0013 & 0.0018 \\
\hline 20.04 .2005 & $-0.0004^{*}$ & 0.0001 & 0.0002 & $0.0009 * * *$ & 0.0005 & 0.001 & -0.0009 & -0.0002 \\
\hline 07.09 .2005 & -0.0001 & 0.0003 & $0.0006^{*}$ & $0.0006^{*}$ & 0.0012 & -0.0003 & 0.0005 & -0.0002 \\
\hline$\%$ signif. & $11 \%$ & $24 \%$ & $6 \%$ & $24 \%$ & $24 \%$ & $7 \%$ & $11 \%$ & $9 \%$ \\
\hline Anova F-stat & $3.24^{*}$ & 0.02 & 0.20 & 0.14 & $6.95 * * *$ & 1.18 & 0.65 & 1.45 \\
\hline Med. Chi-sq. & 0.1 & 0.38 & 1.33 & $5.53 * *$ & $9.30 * * *$ & $2.8^{*}$ & 0.11 & $6.37 * *$ \\
\hline Var. F-test & 1.27 & $1.95 * * *$ & 1.19 & 1.15 & 1.24 & 1.1 & 1.37 & 1.30 \\
\hline
\end{tabular}


Panel B: off market

\begin{tabular}{lccc} 
date & day before & same day & day after \\
\hline 08.04 .2000 & 0.0007 & - & $0.0031^{* *}$ \\
09.01 .2001 & 0.0005 & $-0.0022^{*}$ & -0.0003 \\
28.01 .2002 & -0.0017 & $-0.0027^{* *}$ & 0.0000 \\
02.05 .2002 & 0.0000 & 0.0000 & $0.0035^{* * *}$ \\
$02.05 .2002^{\mathrm{a}}$ & 0.0000 & 0.0000 & $0.0035^{* *}$ \\
04.09 .2002 & 0.0021 & 0.0015 & $0.0028^{* *}$ \\
29.09 .2002 & 0.0005 & - & $0.0026^{* *}$ \\
12.03 .2003 & 0.0002 & -0.0011 & $-0.0036^{* *}$ \\
15.03 .2003 & $-0.0032^{* *}$ & - & $-0.0032^{* *}$ \\
18.03 .2003 & $-0.0032^{* *}$ & $-0.0069^{* * *}$ & $-0.0052^{* * *}$ \\
26.03 .2003 & -0.0011 & -0.0020 & $0.0035^{* * *}$ \\
16.06 .2003 & -0.0011 & 0.0004 & $-0.0031^{* *}$ \\
02.10 .2003 & 0.0006 & $-0.0025^{*}$ & $-0.0024^{*}$ \\
07.11 .2003 & -0.0017 & $-0.0022^{*}$ & 0.0005 \\
26.10 .2005 & $-0.003^{* *}$ & $-0.0033^{* *}$ & -0.0004 \\
& & & \\
\% signif. & $2 \%$ & $7 \%$ & $9 \%$ \\
Anova F-stat & 0.48 & $2.75^{*}$ & 0.13 \\
Med. Chi-sq. & 0.66 & $2.18^{*}$ & 0.41 \\
Varian. F-test & $1.82^{* * *}$ & 1.05 & 1.23 \\
\hline & & &
\end{tabular}

${ }^{a}$ Overlapping events: this interview was preceded by another interview.

${ }^{\mathrm{b}}$ Overlapping events: this interview was preceded by a speech. 
Table 5.4 Effects of central bank communication

\begin{tabular}{|c|c|c|c|c|}
\hline \multicolumn{5}{|l|}{$\begin{array}{l}\text { Foreign } \\
\text { exchange }\end{array}$} \\
\hline & $\alpha$ & $\beta$ & $\mathbf{R}^{2}$ & Variance Ratio \\
\hline Announcements & -0.06 & -0.67 & 0.02 & 8.72 \\
\hline Prob ttest & 0.41 & 0.07 & & 0.00 \\
\hline Speeches & -0.01 & 0.77 & 0.00 & 0.28 \\
\hline Prob ttest & 0.75 & 0.63 & & 0.78 \\
\hline Interviews & -0.02 & -1.48 & 0.07 & 1.88 \\
\hline Prob ttest & 0.42 & 0.09 & & 0.06 \\
\hline \multicolumn{5}{|l|}{ Equity market } \\
\hline & $\alpha$ & $\beta$ & $\mathrm{R}^{2}$ & Variance Ratio \\
\hline Announcements & -0.03 & -0.98 & 0.14 & 0.66 \\
\hline Prob ttest & 0.49 & 0.03 & & 0.52 \\
\hline Speeches & -0.01 & -0.33 & 0.00 & 0.54 \\
\hline Prob ttest & 0.81 & 0.90 & & 0.59 \\
\hline Interviews & 0.00 & -2.54 & 0.04 & 0.78 \\
\hline Prob ttest & 0.93 & 0.23 & & 0.44 \\
\hline \multicolumn{5}{|l|}{ Bond market } \\
\hline & $\alpha$ & $\beta$ & $\mathrm{R}^{2}$ & Variance Ratio \\
\hline Announcements & 0.00 & -0.44 & 0.18 & 3.86 \\
\hline Prob ttest & 0.90 & 0.09 & & 0.00 \\
\hline Speeches & 0.00 & -0.70 & 0.06 & 1.14 \\
\hline Prob ttest & 0.73 & 0.06 & & 0.26 \\
\hline Interviews & 0.00 & -0.40 & 0.07 & 1.30 \\
\hline Prob ttest & 0.53 & 0.10 & & 0.20 \\
\hline
\end{tabular}




\section{Swiss National Bank Working Papers published since 2004:}

2004-1 Samuel Reynard: Financial Market Participation and the Apparent Instability of Money Demand

2004-2 Urs W. Birchler and Diana Hancock: What Does the Yield on Subordinated Bank Debt Measure?

2005-1 Hasan Bakhshi, Hashmat Khan and Barbara Rudolf: The Phillips curve under state-dependent pricing

2005-2 Andreas M. Fischer: On the Inadequacy of Newswire Reports for Empirical Research on Foreign Exchange Interventions

2006-1 Andreas M. Fischer: Measuring Income Elasticity for Swiss Money Demand: What do the Cantons say about Financial Innovation?

2006-2 Charlotte Christiansen and Angelo Ranaldo: Realized Bond-Stock Correlation: Macroeconomic Announcement Effects

2006-3 Martin Brown and Christian Zehnder: Credit Reporting, Relationship Banking, and Loan Repayment

2006-4 Hansjörg Lehmann and Michael Manz: The Exposure of Swiss Banks to Macroeconomic Shocks - an Empirical Investigation

2006-5 Katrin Assenmacher-Wesche and Stefan Gerlach: Money Growth, Output Gaps and Inflation at Low and High Frequency: Spectral Estimates for Switzerland

2006-6 Marlene Amstad and Andreas M. Fischer: Time-Varying Pass-Through from Import Prices to Consumer Prices: Evidence from an Event Study with Real-Time Data

2006-7 Samuel Reynard: Money and the Great Disinflation

2006-8 Urs W. Birchler and Matteo Facchinetti: Can bank supervisors rely on market data? A critical assessment from a Swiss perspective

2006-9 Petra Gerlach-Kristen: A Two-Pillar Phillips Curve for Switzerland

2006-10 Kevin J. Fox and Mathias Zurlinden: On Understanding Sources of Growth and Output Gaps for Switzerland

2006-11 Angelo Ranaldo: Intraday Market Dynamics Around Public Information Arrivals

2007-1 Andreas M. Fischer, Gulzina Isakova and Ulan Termechikov: Do FX traders in Bishkek have similar perceptions to their London colleagues? Survey evidence of market practitioners' views

2007-2 Ibrahim Chowdhury and Andreas Schabert: Federal Reserve Policy viewed through a Money Supply Lens 
2007-3 Angelo Ranaldo: Segmentation and Time-of-Day Patterns in Foreign Exchange Markets

2007-4 Jürg M. Blum: Why ‘Basel II’ May Need a Leverage Ratio Restriction

2007-5 Samuel Reynard: Maintaining Low Inflation: Money, Interest Rates, and Policy Stance

2007-6 Rina Rosenblatt-Wisch: Loss Aversion in Aggregate Macroeconomic Time Series

2007-7 Martin Brown, Maria Rueda Maurer, Tamara Pak and Nurlanbek Tynaev: Banking Sector Reform and Interest Rates in Transition Economies: Bank-Level Evidence from Kyrgyzstan

2007-8 Hans-Jürg Büttler: An Orthogonal Polynomial Approach to Estimate the Term Structure of Interest Rates

2007-9 Raphael Auer: The Colonial Origins Of Comparative Development: Comment. A Solution to the Settler Mortality Debate

2007-10 Franziska Bignasca and Enzo Rossi: Applying the Hirose-Kamada filter to Swiss data: Output gap and exchange rate pass-through estimates

2007-11 Angelo Ranaldo and Enzo Rossi: The reaction of asset markets to Swiss National Bank communication 
Swiss National Bank Working Papers are also available at www.snb.ch, section Publications/Research Subscriptions or individual issues can be ordered at Swiss National Bank, Fraumünsterstrasse 8, CH-8022 Zurich, fax+41 4463181 14, E-mail library@snb.ch 